This is the accepted version of the below article published online 29 January 2014 by Sage in Public Finance Review. Available at: $\underline{10.1177 / 1091142113515049}$

Accepted Version downloaded from SOAS Research Online:

\title{
Federal Transfers and Fiscal Discipline in India: An Empirical Evaluation
}

\author{
Antra Bhatt \\ Dipartimento di Economia Diritto e Istituzioni, \\ Università di Roma Tor Vergata \\ Pasquale Scaramozzino \\ Department of Financial and Management Studies, \\ SOAS, University of London \\ and Dipartimento di Economia Diritto e Istituzioni, \\ Università di Roma Tor Vergata
}

August 2013

\begin{abstract}
This paper examines the relationship between federal transfers and fiscal deficits in India. The system of federal transfers has been criticized on the grounds that it distorts the incentives for states to promote fiscal discipline. We analyze the relationship between transfers, state domestic product, and fiscal deficit for a panel of states during the period 1990-2010. The paper finds a positive long-run relationship and bi-directional causality between primary/gross fiscal deficits and non-plan transfers. Further, there is a negative long-run relationship and one-way causality between state domestic product and transfers. These results are confirmed by multi-variate cointegration analysis, which finds a long-run relationship between fiscal transfers, state product per capita and the primary deficit of the states. The evidence in the paper is consistent with the system of fiscal transfers being "gap-filling".
\end{abstract}

Keywords: federal transfers, India, public finance, panel cointegration, panel ECM.

JEL Classification: H77, R23, C33. 


\section{INTRODUCTION}

Intergovernmental fiscal transfers typically serve a number of different objectives, ranging from dealing with both vertical and horizontal fiscal imbalances to influencing regional and local economic stabilization (Boadway and Shah 2007). The role of fiscal transfers becomes even more relevant in an economy with such large regional inequalities and significant divergences in economic performance as are experienced in India. The main policy challenge for the federal transfer system in India is to assess the economic situation of all the regions periodically and to devise mechanisms and criteria such that fiscal transfers can contribute to the reduction of regional gaps.

An essential component of the design of fiscal transfers is the requirement that they should not generate incentives for the local governments to adopt a loose fiscal stance, in the expectation that the central government will intervene ex post to fund their fiscal deficits. Such an accommodative policy by the central government would reward opportunistic behavior, and discourage the enforcement of fiscal discipline by local governments. The resulting soft budged constraint could also have the consequence of contributing to the persistence of regional inequalities, to the extent that the transfers from the central government could be used to fund non-productive expenditures at the local level.

The extant literature has identified a number of causes for concern with the current Indian federal transfers system. Rao $(2000,2005,2007)$ forcefully argued that it is necessary to bring both more rationality and more equity to the assignment system, and to address the moral hazard associated with fiscal transfers from the Centre to the states. George (2010) pointed out that the process of liberalization that took place in India since the early 1990s has resulted in additional challenges to the federal system, since it created a larger role for the states compared to the central government.

This paper carries out an empirical quantitative investigation of the system of federal transfers in India. It examines the complex relationships between federal fiscal transfers from the central government, state fiscal deficits, and state domestic product per capita. It is thus possible to evaluate the extent to which the current system has been able to address its objective of reducing inequalities across states, or whether it has simply accommodated fiscal imbalances. 
The paper makes use of a data set on Centre-state transfers and state fiscal deficits over the period 1990-2010. It investigates whether there is evidence in the data on one of the main causes for concern, i.e. the "gap-filling" nature of federal transfers. The paper tests for the existence of a long-run relationship, for the direction of causality and for the nature of the relationships of transfers with state domestic product and with deficit respectively. The existence of a bi-directional causality between transfers and deficit, along with the existence of a strong cointegration relationship, would lend support a "gap-filling" role for the transfer system. Furthermore, if there exists a positive co-integration relationship between transfers and net state domestic product (NSDP) per capita, with unidirectional causality from NSDP to transfers, this would imply that the transfer system does not help close the regional gaps between poorer and richer states.

We check for the robustness of our results by investigating the co-integration between the variables over the longer period 1981-2010. Unfortunately it is not possible to separate plan and non-plan transfers over the longer sample period, so we consider total transfers in these analyses. The main results are reinforced, and confirm the existence of a long-run relationship between state domestic product, deficits and transfers. The results are also confirmed when we consider additional variables as controls in the multi-variate relationships.

The next sections of the paper are organized as follows. Section II presents a brief discussion of regional inequalities and Centre-state relations in India. Section III illustrates the determinants of plan and non-plan transfers. Section IV describes the dataset and outlines the empirical framework and the estimation equations. Section V presents the results of the empirical analysis while Section VI discusses the main conclusions. 


\section{REGIONAL INEQUALITIES AND CENTRE-STATE RELATIONS}

\section{A. Centre-State Relations in India}

In order to understand the system of federal transfers in India, it is important to consider the relationship between central and state governments within the constitutional set up of the Indian Union. In the aftermath of independence, the founding fathers were weary of allocating significant responsibilities to the states because of the perceived risk of encouraging further fissiparous tensions. They opted instead for a centralized federal union, with strong powers allocated to the central government (Arora 2010). According to the constitution it was the responsibility of the Union Parliament and of the central government to recognize diversity across states, although the management of the socio-political consequences of diversity was left to state governments. The state governments were directly responsible for the administration of urban and rural local governments. In particular, the latter were required to oversee the functioning of local government units in rural areas, i.e. the district, block, and village panchayat (Bagchi 2003). In practice, the constitutional set up could not prevent some ambiguity in the relationships between the Centre and the state governments. Over the course of time, the consolidation of democratic processes in Indian polity has shifted the Centre-state balance towards greater decentralization, with an increased role for the states.

The original concern with centrifugal pressures is also apparent in the allocation of prerogatives for the central and the state governments respectively, as set out in the Indian constitution. The legislative powers over the various economic activities are divided into three broad areas: areas reserved for Centre (Union list), areas reserved for States (State list), and areas of joint jurisdiction (Concurrent list). Areas of national importance such as defense, foreign affairs, international trade and macroeconomic management are the responsibility of the Centre. Major economic activities (including national highways and airways) and their supervision responsibility are also assigned exclusively to the Centre. However, in practice the Centre also contributes to some of the areas that fall within the responsibility of the states (Bagchi 2003): the State list includes law and order, public health, sanitation, schools, irrigation, agriculture, fisheries, industries, land rights, local government, and other sectors with state-wide effects. Secondary and adult education, housing and land use, electricity distribution, and industrial and

commercial estates are instead assigned to urban and local governments. The concurrent list 
comprises items such as education, contracts, bankruptcy and insolvency, economic and social planning, trade unions, labor welfare, electricity, newspapers, books and printing press, and stamp duties.

The complex allocation of responsibilities between the central government and the states could lead to large vertical imbalances, if the fiscal resources available to the states prove inadequate to meet their expenditure obligations. A system of federal fiscal transfers is therefore necessary in order to address these needs. The two main bodies that oversee fiscal transfers are the Finance Commission and the Planning Commission. The mandate of the Finance Commission is to facilitate the fiscal transfers between the Centre and the states, with a view to addressing vertical and horizontal imbalances. Its main functions are to distribute net proceeds of taxes between the Centre and the states, to determine grants-in-aid to the states, and to liaise with State Finance Commissions. The main charge of the Planning Commission is to make an assessment of all resources of the country, and to determine priorities and formulate plans for their effective and balanced utilization.

There are three main channels that regulate the flow of funds from the Central government to the states in India (Herd and Leibfritz 2008). First, the Finance Commission recommends which proportions of the Centre's taxes (notably, personal income tax and union excise duty) should be transferred to the states. Second, the Planning Commission grants central assistance to projects or schemes. Third, the Planning Commission directly administers selected schemes of government expenditure.

\section{B. Regional Inequalities}

The recent literature on regional inequalities in India has confirmed increased divergence across states in terms of their NSDP per capita. Not only have the differences in income per capita not declined over time during the recent decades, but the very richest states have also experienced the highest rates of growth, which further exacerbated the initial inequalities. A number of reasons have been suggested to explain this widening discrepancy. Nagaraj, Varoudakis, and Vèganonès (1998) showed that differences in the levels of infrastructure can be the single most important determinant of the relative success or failure across states. More recently, Bhattacharyya and Sakthivel (2004) and Purfield (2006) have attributed the increasing regional divergences to the ability of the richer states to attract more foreign investment relative to their poorer counterparts. 
Alessandrini, Buccellato, and Scaramozzino (2008) also emphasize the importance of geographical factors, which made it difficult for some states to increase their volume of trade in the post-reform period. Further, Alessandrini, Fattouh, Ferrarini, and Scaramozzino (2011) show that trade reforms were instrumental to enhance India's international competitiveness: however, not all the states were able to benefit equally from trade liberalization.

Bandyopadhyay (2012) finds evidence of two convergence clubs, one at 50 percent and another at 125 percent of average national income. Capital expenditures, fiscal deficits, and education expenditures all played a crucial role in the formation of the upper convergence club. In particular, the system of fiscal transfers from the Centre to the states could have contributed to the persistence of regional inequality, because countries with higher levels of deficit usually tended to receive a larger amount of transfers.

The figures on NSDP per capita, debt and transfers in Table 1 show an almost four-fold increase in real state debt as a percentage of NSDP over the sample period, from 7.7 percent in 1990 to 27.5 percent in 2010. Total transfers increased much less during this period, from 20.9 percent to 21.1 percent (from 12.7 percent to 14.0 percent for non-plan transfers). On average, richer states have both lower debt and receive less transfers than poorer counties: the correlation coefficients between NSDP per capita and debt across all states are -0.35 in 1990 and -0.37 in 2010, whilst the correlation coefficients between NSDP per capita and total transfers are -0.21 in 1990 and -0.27 in 2010. High-debt states also received on average higher transfers, although the correlation weakened over time: the correlation coefficient between debt and non-plan transfers was 0.65 in 1990 but only 0.13 in 2010 (the corresponding correlations between debt and total transfers were 0.69 and 0.23 ).

On average, special category states have both higher levels of debt and of transfers than non-special category states (see also section III below): debt as a percentage of NSDP was 33.74 percent in the former states and 23.01 percent in the latter in 2010, and total transfers were 44.06 percent and 4.73 percent respectively in 2010 .

Additionally, the allocation of these federal transfers is also affected by political economy considerations. Biswas and Marjit (2000), Rao and Singh (2000, 2001, 2002), and Dasgupta, Dhillon and Dutta (2001) show that political factors such as the proportion of the ruling party's 
Members of Parliament (lower house only) coming from a particular state, whether the same party was in power at the center and the state level, and the representation of different states in the ministerial cabinet can matter for analyzing the pattern of transfers in India. Arulampalan, Dasgupta, Dhillon and Dutta (2009) expand on their earlier study to show that the central government used some discretion in the allocation of transfers. In particular, states that are aligned to the central government receive on average higher transfers in comparison to the other states.

\section{THE SYSTEM OF FISCAL TRANSFERS}

The focus of the empirical analysis of this paper is on the plan and non-plan grants provided by the Planning Commission and by the Finance Commission.

Plan grants are provided by the Planning Commission. This supplies financial assistance to states in the form of grants and loans. Before 1969, central assistance was provided for by the central government on an ad hoc basis. However, this proved inadequate to promote the constitutional goal of balanced growth. In order to favor balanced growth some states with features such as hilly terrain, international borders, significant tribal population and low level of infrastructural development were given the status of special category (SC) states. For the rest of the states, specific criteria for devolution were chosen. About 30 percent of the funds are now reserved to the special category states, and the remaining 70 percent are allocated to the major states.

The funds made available to the major states are assigned according to the Gadgil formula, which specifies that these funds must be allocated on the basis of a fixed number of indicators, with a given system of weights: population (60 percent), per capita income (25 percent), tax effort (2.5 percent), fiscal management ( 2 percent), fulfillment of national objectives such as population control and elimination of illiteracy (3 percent), and special problems (7.5 percent). The Gadgil formula, which in its revised form came to be known as the Gadgil-Mukherjee formula, helped improve objectivity, transparency and progressiveness. The economic rationale behind using population as one of the weights was the negative observed correlation between population and state per capita income. Similarly, to reduce regional inequality and to deal with 
bigger states getting more funds due to their bigger plans, state per capita income was also used as a weight (Ramalingom and Kurup 1991).

Non-plan transfers are provided by the Finance Commission. These transfers are also determined according to a set of rules, whose weights however differ from those in the Gadgil formula even though their economic rationale is the same. Specifically, the criteria used for tax devolution, with their respective weights used in the late 1990s, are population (10 percent), income (62.5 percent), area (7.5 percent), index of infrastructure (7.5 percent), tax effort (5 percent), and fiscal discipline (7.5 percent) (Rao 2000, Bird and Vaillancourt 2007). Centrally sponsored schemes have also become more prominent in recent years, as well as borrowing in order to finance infrastructure at the state level.

The weights of the variables used in the tax devolution formula are revised in each successive finance commission report. For instance, the horizontal devolution formula proposed by the Twelfth Finance Commission assigned a weight of 25 percent to population, 50 percent to per capita income distance, 10 percent to area and 7.5 percent each to tax effort and fiscal discipline. However, these weights were revised by the Thirteenth Finance Commission as follows: 25 percent to population, 47.5 percent to fiscal capacity distance, 10 percent to area and 17.5 percent to fiscal discipline (Thirteenth Finance Commission, 2010). The Finance Commission estimates the total resources of the centre and the states and then proposes a pattern for tax-sharing (Mohan 1998). This is closely linked with the state income and hence the state own tax revenue. States with higher income have a wider tax base and need less tax devolution from the Centre.

In principle, the three main aims of intergovernmental fiscal transfers are: (i) closing vertical fiscal gaps; (ii) equalization and horizontal equity; and (iii) correct spillovers across local jurisdictions (Rao 2005). The post-devolution projected gaps between non-plan current expenditures and revenues have been covered by the Finance Commission through grants-in-aid. States which exhibited higher levels of deficit were able to fund their fiscal imbalance through these transfers. This resulted in a potential "gap-filling" role for fiscal transfers. Such an accommodative transfer policy could create perverse incentives, undermining the attempts by states to pursue fiscal discipline (Rao 1998, 2005, McCarten 2001). It could also exacerbate regional inequalities, since states would not always receive funds on account of their needs or of 
the effectiveness in their use of funds, but also on the basis of the extent to which they have engaged in fiscal profligacy (Rao 2000).

A number of these issues were addressed by the Thirteenth Finance Commission (THFC), which covers the period 2010-2015 and which made recommendations that would lead to enhanced fiscal responsibilities for the states and to increased incentives for them to undertake a process of fiscal consolidation, according to a specific road map (THFC 2010). In some states, the temporary deficit on account of the gap between the short-term mismatch between revenue and expenditures has been transformed into a structural deficit, and fiscal reforms have been called for to improve the fiscal situation. Further, the recommendation has been put forward to revise the criteria for the non-plan revenue deficit (NPRD) grants. The focus will be on assessing the components of revenues and expenditures of states, in order to ensure that the deficit is not due to inappropriate revenue effort or excessive expenditure. Further, states which are able to reduce their fiscal deficit and to improve their fiscal performance should be given a performance incentive grant. Finally, the Commission also recommended reducing the number of centrally sponsored schemes and restoring formula-based transfers.

\section{DATASET AND EMPIRICAL FRAMEWORK}

\section{A. Description of Dataset}

This study uses a panel of 24 Indian states over the period 1990-2010 to examine how transfers, both plan and non-plan, are related to net state domestic product (NSDP) per capita and to fiscal deficits. The analysis focuses on the post-reform period, and this motivates the choice of the sample period. All variables have been deflated to obtain real values. Net State Domestic Product (NSDP) has been used in preference to Gross State Domestic Product (GSDP) because of the following reasons. First, net output can be regarded as more appropriate for the analysis of economic growth and of welfare issues (Denison 1985; Hulten 1992, 2005). Secondly, the sensitivity of state domestic product to the particular choice of a quality-adjusted investment deflator is reduced by using output net of depreciation (Diewert, Fox 2005). As a matter of fact, many articles in the extant literature on state finances in India such as Bajpai and Sachs (1999), Rao (2002) and Rao (2003) have used net domestic output values in their empirical analysis. 
The panel dataset consists of data on loans, deficit (primary, gross fiscal deficit), plan transfers, non-plan transfers and their components including the breakdown of revenue receipts of the government. The break-up of development expenditures is also collated. These data have been obtained from the RBI Handbook of Statistics on State Finances, 2010, Economic Survey of India - various issues, Central Statistical Organization-NAS and the IMF Database among others. Table A1 lists each variable along with the corresponding data source. The states excluded from the analysis are listed in the footnote accompanying the table.

In our estimation strategy we make use of panel methods which efficiently combine both the time-series and the cross-section dimensions of the observations. This can help address the issue of the relatively short time period of the analysis. On the other hand, we also re-estimated some of the long-run equilibrium relationships using total transfers over the longer sample period 1981-2010, and the main results are unaffected.

After examining the univariate time-series properties of each series, we implement Granger-causality tests in order to examine the direction of the relationships between transfers, NSDP per capita and fiscal deficits. Ideally, states with lower NSDP should be entitled to higher transfers and vice versa (see section II.B). A bi-directional negative long-run causality between transfers and NSDP per capita would thus indicate that transfers from the central government to the states would tend to accrue to the poorer regions, and that these funds could contribute to the lessening of the regional inequalities across Indian states. On the other hand, a positive bidirectional long-run relationship between transfers and fiscal deficits would indicate that central government funds tend to accrue to those states which have been less rigorous in terms of enforcing fiscal discipline. This could effectively result in a soft budget constraint for the state governments: if fiscal deficits were shown to Granger-cause plan and/or non-plan transfers, there would be a reduced incentive for states to generate their own tax revenues and to improve their fiscal balance. Further, exploring both bi- and multi-variate relationships is important in order to study the combined as well as the pair-wise relationships between the variables of interest.

\section{B. Econometric Methodology}

The univariate time-series properties of plan and non-plan transfers, NSDP per capita and fiscal deficits are first examined by means of panel stationarity tests in order to establish whether 
the series are I(0) or I(1) (Breitung 2000, Hadri 2000, Im, Pesaran, and Shin 2003, and Levin, Lin, and Chu 2002). Bi-variate and multi-variate cointegration tests between the variables are then implemented in order to check for the existence of a significant mean-reverting long-run relationship (Kao 1999 and Pedroni 1999, 2004). The direction of causality between plan and non-plan transfers, GSDP per capita and fiscal deficit is then examined by Granger causality tests. In particular, if state deficits are shown to Granger-cause fiscal transfers from the Centre, this could be seen as evidence that the implementation of the transfer system tends to accommodate the fiscal imbalances of the states.

The use of a panel data approach for the analysis offers a number of advantages. First, it becomes possible to explore both the time-series and the cross-section aspects of the relationships between transfers, fiscal indicators, and the level of income of the individual states. Secondly, it is possible to address issues associated with the potential endogeneity of the variables. On the other hand, because of the relatively short time-series dimension of the sample (which, for most of our analysis, includes annual observations from 1990 to 2010), it is possible that some of the results might be sensitive to the lag length used in the analysis. In order to address this issue, we implement a procedure for error correction model (ECM) testing of panel data originally suggested by Westerlund (2007). The procedure includes four panel cointegration and ECM tests. The main advantages of the approach by Westerlund are that it is based on structural rather than on residual dynamics, and that it does not impose the common factor restriction that the long-run cointegrating vector for the variables in levels must be equal to the short-run dynamics on the variables in differences (see Kremers, Ericsson, and Dolado 1992). The presence of bi-variate and multi-variate cointegrating relationships is tested by verifying whether there is error correction for individual units of the panel or for the panel as a whole. The tests proposed by Westerlund control for heterogeneity across the units of the panel, both in the short run and in the long run. The tests can also allow for dependence across individual cross-sections.

The estimation equations are as follows. The basic auto-regressive model for testing unit roots can be expressed as:

$$
y_{i t}=\rho_{i} y_{i, t-1}+\delta_{i} x_{i t}+\varepsilon_{i t}
$$

where $i=1,2, \ldots, N$ denote the states, $t=1,2, \ldots, T$ is the time index, the vector $x_{i t}$ includes the exogenous variables, and $\varepsilon_{i t}$ is a stationary disturbance. The dependent variable $y_{i t}$ is the amount 
of transfers (plan, non plan or total transfers depending on the specification). The vector of exogenous variables $x_{i t}$ includes NSDP per capita, primary deficit and gross fiscal deficit. The vector $x_{i t}$ can also contain fixed effects or individual trends. Even though most of the analysis is performed as per the above specifications, some tests are also conducted as per reverse causality cointegration. In this case, both plan and non-plan transfers are in the set of regressors with other factors considered as dependent variables in separate cointegrated models. The autoregressive coefficients $\rho_{i}$ are allowed to vary across states. The stationarity properties of equation (1) depend on the value of the autoregressive coefficients $\rho_{i}$. If $\rho_{i}<1$, then $y_{i t}$ is weakly trend stationary. By contrast, if $\rho_{i}=1$ then $y_{i t}$ has a unit root. The tests $L L C$ by Levin, Lin, and Chu (2002), BRT by Breitung (2000) and the $z$-statistic by Hadri (2000) all assume that the disturbances $\varepsilon_{i t}$ are $\operatorname{IID}\left(0, \sigma^{2}\right)$ and that the autoregressive coefficients are constant across the cross-section: $\rho_{i}=\rho$ for all $i$.

A bi-variate and multi-variate panel cointegration relationship between appropriate subsets of variables is then investigated. In this case, $y_{i t}$ represents transfers (non-plan, plan or total transfers) and $x_{i t}$ represents NSDP per capita, primary deficit or gross fiscal deficit. The same cointegration test is repeated for each pair separately and for the three variables together. Each variable is decomposed into common factors and idiosyncratic components, and the variables are cointegrated only if their common factors cointegrate. Since the idiosyncratic components are independent by construction, it is possible to use standard panel tests such as Kao (1999) and Pedroni $(1999,2004)$ in order to study their properties.

The testable equations for the ECM representation developed by Westerlund $(2007)^{1}$ can be expressed as:

$$
\Delta y_{i t}=\delta_{i}^{\prime} d_{t}+\alpha_{i}\left(y_{i, t-1}-\beta_{i}^{\prime} x_{i, t-1}\right)+\sum_{j=1}^{p_{i}} \alpha_{i j} \Delta y_{i, t-j}+\sum_{j=-q_{i}}^{p_{i}} \gamma_{i j} \Delta x_{i, t-j}+e_{i t}
$$

The variable $\boldsymbol{d}_{\boldsymbol{t}}$ denotes the deterministic component. Three cases can be distinguished: (i) no deterministic component, i.e. $\boldsymbol{d}_{\boldsymbol{t}}=\mathbf{0}$; (ii) a constant but no trend, i.e. $\boldsymbol{d}_{\boldsymbol{t}}=\mathbf{1}$; and (iii) a constant and a trend, i.e. $\boldsymbol{d}_{\boldsymbol{t}}$ is a vector: $\boldsymbol{d}_{\boldsymbol{t}}=(\mathbf{1}, \boldsymbol{t})^{\prime}$. Westerlund (2007) assumes that the vector $\boldsymbol{x}_{\boldsymbol{i t}}$ follows a random walk, and therefore $\boldsymbol{\Delta} \boldsymbol{x}_{\boldsymbol{i t}}$ and $\boldsymbol{e}_{\boldsymbol{i t}}$ are independent both across $i$ and $t$. However, it is possible to allow for dependence across the cross-sectional units $i$ by bootstrap methods.

\footnotetext{
${ }^{1}$ See also Persyn and Westerlund (2008) for details of how the estimation procedure is implemented.
} 
The Error Correction Model (2) can be rewritten in an unrestricted form as:

$$
\Delta y_{i t}=\delta_{i}^{\prime} d_{t}+\alpha_{i} y_{i, t-1}+\lambda_{i}^{\prime} x_{i, t-1}+\sum_{j=1}^{p_{i}} \alpha_{i j} \Delta y_{i, t-j}+\sum_{j=-q_{i}}^{p_{i}} \gamma_{i j} \Delta x_{i, t-j}+e_{i t}
$$

where the relationship between the parameters in equations (3) and (2) is given by $\lambda_{i}^{\prime} i=-\alpha_{i} \beta_{i}^{\prime}$. The autoregressive parameter $\alpha_{i}$ on the lagged dependent variable in (3), $y_{i, t-1}$, captures the speed at which the variable returns to the equilibrium given by the relationship $y_{i, t-1}-\beta_{i}^{\prime} x_{i, t-1}$ from equation (2). In the formulations (2) and (3), cointegration and error correction are closely related: if $\alpha_{i}<0$ then there is error correction and $y_{i t}$ and $x_{i t}$ are cointegrated, whereas if $\alpha_{i}=0$ then there is no error correction and $y_{i t}$ and $x_{i t}$ are not cointegrated.

The null hypothesis of the test can be expressed in terms of no cointegration: $H_{0}: \alpha_{i}=0$ for all $i$. The alternative hypothesis is in general different according as to whether one requires that all $\alpha_{i}$ 's are equal across the cross-sectional units, or whether the $\alpha_{i}$ 's are allowed to differ across the panel members. Westerlund (2007) proposes two tests for the dis-homogenous case, where the alternative hypothesis is $H_{1}^{g}: \alpha_{i}<0$ for at least one $i$. These tests are called groupmean tests, and are denoted by $G_{\tau}$ and $G_{\alpha}$ respectively. ${ }^{2}$ Similarly two tests are proposed for the homogeneous case, where the speed of adjustment $\alpha_{i}$ is equal for all $i$ and where the alternative hypothesis is $H_{1}^{p}: \alpha_{i}=\alpha<0$ for all $i$. These tests are called panel tests, and are denoted by $P_{\tau}$ and $P_{\alpha}$ respectively. ${ }^{3}$

The group-mean tests and the panel tests are based on the assumption of cross-sectional independence. Westerlund (2007) therefore suggests recomputing the test statistics using a bootstrap method, which is valid under very general forms of dependence between the crosssectional units. The empirical analysis in the next section reports Westerlund's tests both without and with bootstrapping.

\section{EMPIRICAL RESULTS}

\section{A. Plan and Non-plan Transfers, NSPD per Capita and Fiscal Deficits}

\footnotetext{
${ }^{2}$ The test statistic $G_{\alpha}$ is normalised by the number of time series observation $T$.

${ }^{3}$ Again, the test statistic $P_{\alpha}$ is normalised by the number of time series observation $T$.
} 
Table 2 shows the correlation coefficients between plan and non-plan transfers and both primary and gross fiscal deficits over the sample period 1990-2010 for the whole panel of state observations. The correlation between plan and non-plan transfers is positive and large, which indicates that, on average, states that received higher plan transfers also received higher non-plan transfers and vice versa. Both types of transfers are positively correlated with primary and gross fiscal deficits.

Figures 1 (a) and (b) plot both plan and non-plan transfers against the primary deficits. We can observe a clear positive relationship both for plan and for non-plan transfers, which is prima facie evidence in favor of a gap filling role of fiscal deficits.

In order to shed further light on the relationship of transfers with the primary deficit, the adjusted partial residual plots are shown in Figures 2 (a) and (b). These figures display each observation's residual, plus its component predicted from NSDP per capita, against the values of primary deficit. They illustrate the relationship between transfers and fiscal deficits controlling for NSDP per capita. The positive associations from Figure 1 are reinforced, which again is suggestive of a potential accommodating role for fiscal transfers.

\section{B. Panel Stationarity}

Before proceeding to the analysis of the cointegration of the variables, it is necessary to establish their stationarity properties. This is done in Tables 3a and 3b. All the panel unit root tests examined in the tables, with the exception of the Hadri $z$-statistic, test for the existence of a unit root in a series. Hence, if the $t$-statistic falls within the rejection region and the $p$-value is low, the null hypothesis can be rejected and the series are stationary. For the Hadri z-statistic, a low $p$ value would instead be evidence in favor of non-stationarity.

For NSDP per capita and for non-plan transfers, all the tests except some of the Hadri $z$ statistics support the hypothesis that the series are non-stationary in levels and stationary in the first differences. For NSDP per capita and for plan and non-plan transfers, the Hadri $z$-statistics do not support the hypothesis that the series are stationary in the first differences. However, all other five tests do support this hypothesis. These series are thus classified as weakly stationary in first differences. For primary deficit and for gross fiscal deficit, all the six tests lend support to the hypothesis that the series are non-stationary in levels and stationary in first differences.

\section{Multivariate Panel Cointegration}


The panel cointegration tests can be performed on a dataset in which the variables in discussion are non-stationary in levels and stationary in first differences. This was confirmed with the help of the panel stationarity tests reported in Tables 3. In the multi-variate panel cointegration tests NSDP per capita, primary deficit, and gross fiscal deficit respectively are first tested for a longrun relationship with non-plan and plan transfers.

The first set of tests is the Pedroni test (Table 4a), which generates both group and panel statistics. Between NSDP per capita and plan, non-plan transfers, two of the group statistics indicate the presence of cointegration. The panel statistics corresponding to the same set of variables do not show any evidence of cointegration. However, when NSDP per capita is considered jointly with deficits and total transfers, two of the three group statistics and three of the four panel statistics show strong evidence of cointegration.

When the cointegration between deficits (primary and gross) and transfers (total and plan, non-plan) is tested, two of the three group and four panel statistics show evidence of cointegration. Further, when NSDP per capita is introduced in the equation, the results are strengthened further wherein two of the three groups and three of the four panel statistics support the existence of a cointegration.

We validate these results by performing the additional tests of cointegration summarized in the first three rows of Table 4b. Both Fischer and Kao (1999) tests reject the null hypothesis of no cointegration. Hence, all sets of variables are cointegrated in the multi-variate framework. From the Kao (1999) tests we can also obtain the cointegration coefficients (for first differences) which confirm the positive relationship between transfers and the primary deficit and gross fiscal deficit respectively.

These results confirm that NSDP per capita shares a long-run relationship with both types of transfers. On the other hand, the long-run relationship between the fiscal deficits and the nonplan and plan transfers lends support to the hypothesis that the system of federal transfers is strongly influenced by the level of deficits in the state. The nature of relationship between the two confirms the fact that states with higher deficits are usually provided with higher transfers in the long run.

The bottom three rows of Table $4 \mathrm{~b}$ look at the joint cointegrating relationship between NSDP per capita, fiscal deficits and transfers. Again all the tests reject the null hypothesis of no 
cointegration. There is therefore evidence of a long-run relationship between NSDP per capita, fiscal deficits and federal transfers for the Indian states.

In addition to the above results, we also examine the intensity of the cointegration relationship within the panel by considering two sources of heterogeneity across states: the level of income (Tables $4 \mathrm{c}$ and $4 \mathrm{~d}$ ) and the special category status (Tables $4 \mathrm{e}$ and $4 \mathrm{f}$ ). The tables report the results of estimation of the panel cointegration relationships between NSDP per capita, primary and gross fiscal deficits, and total transfers. Tables $4 \mathrm{c}$ and $4 \mathrm{~d}$ classify the states into three categories: high, middle, and low income based on their NSDP per capita. The results of the Pedroni tests as can be seen in Table $4 \mathrm{c}$ do not show evidence of cointegration. However, some of the Fischer and Kao (1999) tests in Table 4d reject the null of no cointegration. There is therefore some evidence of one cointegrating vector between the variables even within each one of the income categories.

Tables $4 \mathrm{e}$ and $4 \mathrm{f}$ classify states according to their special category status. From Table 1, special category states tend on average to receive much larger amounts of transfers. The Pedroni tests in Table 4e do not however show evidence of cointegration within special category and nonspecial category states. Similarly, there is no evidence of cointegration among special category states from the Fischer and Kao (1999) tests in Table 4f. By contrast, there is evidence of cointegration within the non-special category states. Hence, despite receiving on average much larger transfers, there is no evidence of a different long-run relationship between NSDP per capita, primary and gross fiscal deficits, and total transfers for special category states.

\section{Direction of Causality}

The results in Table 4 have established the existence of a long-run relationship between state income, fiscal deficits and transfers. Table 5 examines the direction of causality between these variables. NSDP per capita, primary deficit and gross fiscal deficit all Granger-cause both plan and non-plan transfers. It is important however to note that neither category of fiscal transfers Granger-causes NSDP per capita. Thus, although poorer states have received, on average, larger fiscal transfers from the central government than richer states, there appears to be no evidence from the analysis that these transfers have led to higher state incomes.

By contrast, fiscal transfers are seen to Granger-cause fiscal deficits. These results could be read as evidence that fiscal transfers may have encouraged state governments to implement 
less rigorous fiscal policy, in the expectation that the transfer system would accommodate ex post their fiscal imbalances.

\section{E. ECM-based Cointegration Tests}

Table 6 reports the results of bi-variate ECM-based cointegration tests (Westerlund, 2007). The variables considered are NSDP per capita, primary deficit and gross fiscal deficit. Their long-run relationship with plan and non-plan transfers is tested. The table reports the $p$-values of one-sided cointegration tests based both on the normal distribution $\left(G_{\tau}, G_{\alpha}, P_{\tau}\right.$, and $\left.P_{\alpha}\right)$ and on the bootstrapped distribution $\left(G_{\tau}(B), G_{\alpha}(B), P_{\tau}(B)\right.$, and $\left.P_{\alpha}(B)\right)$. The bootstrap tests are to be preferred, because they allow for cross-sectional dependence across the regions.

NSDP per capita is cointegrated with both types of transfers. This is evidence of a longrun relationship between fiscal transfers, both plan and non-plan, and state income per capita. This finding is consistent with the results of the previous analysis and confirms that poorer stated do tend to receive higher transfers, although from Table 5 there is no evidence that fiscal transfers help predict future state income.

Non-plan transfers appear to be in an equilibrium relationship with fiscal deficits in the long run, thus confirming the accommodative role of these transfers with respect to the state fiscal policy. However when NSDP is excluded from the analysis there is no support for a longrun bi-variate relationship between fiscal deficits (both primary and gross) and plan transfers, although there is evidence of cointegration between deficits and non-plan transfers. These results would appear to suggest that plan transfers from Central government are related both to state fiscal deficits and to NSDP per capita in the long run.

Table 7 presents ECM-based tests on multi-variate long-run relationships among different sub-sets of variables. When NSDP per capita is considered with deficits and total transfers, there is no evidence of cointegration between the variables $\left(G_{\tau}(B), G_{\alpha}(B), P_{\tau}(B)\right.$, and $\left.P_{\alpha}(B)\right)$. However, when NSDP per capita is separately considered with plan and non plan transfers, a strong cointegration is observed in both the group mean and pooled statistics. This indicates that individual states and the panel as a whole are strongly cointegrated with regard to NSDP per capita and transfers. When fiscal deficits (both primary and gross) are considered with the two types of transfers one group statistic and both the pooled statistics support the existence of a long- 
run cointegrating relationship. Thus, it can be seen that there is weak cointegration in the crosssection and a strong cointegration in the panel.

The last two rows of Table 7 introduce state debt as an additional variable in the equilibrium relationship between NSDP per capita, primary deficits, and transfers. There is strong evidence of cointegration of state debt with both plan and non plan transfers. The stock of state debt could therefore also play a role in the long-run equilibrium relationship between transfers, state income and fiscal variables.

Table 8 extends the ECM-based tests to the sample period 1981-2010. The breakdown between plan and non-plan transfers is not available over this longer period, and therefore the estimates are based on total transfers. If one compares and contrasts the results with the corresponding ones from Table 6, the main findings are all confirmed. The bootstrap tests show that NSDP per capita, primary deficit and total transfers are co-integrated in the long run. The precision of the estimates tends to be greater over this longer sample: the significance level of the tests improves, especially for gross fiscal deficits which now become statistically significant.

Over the longer time period 1981-2010, Zivot-Andrews (1992) tests also show that a number of states experienced a structural break in the series for primary deficits over the period across a number of states from 2003 to 2005 (Table 9). Similarly, total transfers tended to experience structural break over the years 2004-2005. These breaks could be associated with the enactment of the Fiscal Responsibility and Budget Management (FRBM) Act 2003, which set targets to reduce the fiscal deficit and ensure long-run fiscal stability for India. However, the FRBM may not be the only reason for the observed breaks. The breaks can also be attributed to the fact that the income tax revenues were increasing at over 30 percent per year on average from 2004-05 to 2007-08 when the economy was booming. Further, the share of the states in central taxes was around 31.5 percent due to which the states' fiscal position improved substantially. As a result, structural breaks could be seen in both primary deficits and transfers.

\section{F. ECM-based Cointegration Tests with Additional Controls}

The section on regional inequalities presented summary statistics of selected variables and discussed the fact that apart from the variables considered in the empirical analysis, federal transfers can be affected by a number of other factors (Fischer 1993). For instance, structural and 
macro-economic factors such as the size of the agricultural and industrial sector, social security expenditure of the state (health, education etc.) and the ratio of interest payment to revenue receipts are also representative of the fiscal health of the state. Thus, to deepen the analysis done so far, the ECM was re-estimated with the above stated additional controls, to test whether the existence of a long-run relationship is still obtained when the above variables are also taken into consideration. The results in Table 10 show that even when the above factors are considered, there is evidence of a strong cointegration between of primary deficit and gross fiscal deficit with transfers. The same is the case with NSDP per capita, primary deficit and transfers. This can be seen from the rejection of the null of no cointegration by all bootstrap coefficients (both group and pooled). However, the cointegration is weak when state debt is also introduced in the estimation. Thus, while additional macro-economic controls reemphasize the long-run relationship between transfers, NSDP per capita and primary, gross fiscal deficit, the same cannot be said about state debt once the additional controls are also included in the analysis.

In summary, there is evidence of a long-run equilibrium relationship between fiscal transfers, NSDP per capita and the primary deficit of the states. Thus, after controlling for the level of income, fiscal transfers from the Centre tend to be related to the fiscal stance of the states. This evidence strongly supports the view that transfers have played an ex post accommodative role with respect to the fiscal imbalances of the state governments. It will be important to verify if the recommendations for fiscal restructuring between the Centre and the states put forward by the Thirteenth Finance Commission (THFC 2010) will indeed bring about both an increase in the degree of devolution and enhanced fiscal responsibility for the states.

\section{CONCLUSIONS}

Bridging the gap between the economically and socially divergent regions in a developing country like India is a challenging task. A common way of dealing with this task is to provide additional financial support to the less well-off states in order to help them develop and compete with their richer counterparts. However, attention needs to be paid to the overall determinants of such transfers in a federal set up. There could be a temptation to direct transfers to those states with the largest fiscal imbalances, and therefore with the largest need to meet short-term funding requirements, rather to the states with the greatest long-term needs. This would undermine the 
credibility of the central government when it tries to enforce a binding budget constraint on the state governments, and could lead to a reduced effort by states to raise their own revenue and to a more accommodating fiscal policy.

This paper analyses the long-run relationships between federal transfers, NSDP per capita and state fiscal deficit. The evidence is supportive of the view that the Indian federal transfers system is indeed "gap-filling" in nature, with a positive bi-directional long-run relationship between fiscal transfers and deficit. In addition there is also evidence of a unidirectional causality relationship between NDSP per capita and transfers, with the direction of causality going from NSDP per capita to transfers. These results are confirmed by multi-variate cointegration analyses, which find evidence of a long-run equilibrium relationship of fiscal transfers with both NSDP per capita and the primary deficit of the states.

Whilst the system of federal transfers in India has been successful in directing resources towards the poorer states, it may have been less effective in enforcing the incentives for local states to strengthen their fiscal discipline. The transfers from the central government have been systematically used in order to accommodate the fiscal imbalances of the states.

At the same time, there is doubt on the effectiveness of transfers regarding their role in closing the gap between richer and poorer states. At a time when the process of liberalization that took place in India since the early 1990s has called for a larger role for the states relative to the central government, it is important that policy should be directed at enhancing the revenue raising capabilities of the states and at improving their fiscal discipline and accountability. 


\section{REFERENCES}

Alessandrini, Michele, Tullio Buccellato, and Pasquale Scaramozzino. 2008. Whither the Indian Federation? Regional Disparities and Economic Reforms. Rivista Italiana degli Economisti 13 (3): 367-399.

Alessandrini, Michele, Bassam Fattouh, Benno Ferrarini, and Pasquale Scaramozzino. 2011. Tariff Liberalization and Trade Specialization: Lessons from India. Journal of Comparative Economics 39 (4): 499-513.

Arora, Balveer. 2010. Republic of India. In Luis Moreno and Cesar Colino, eds. Diversity and Unity in Federal Countries. McGill-Queen's University Press: 200-226.

Arulampalam, Wiji, Sugato Dasgupta, Amrita Dhillon and Bhaskar Dutta. 2009. Electoral Goals and Center-State Transfers: A Theoretical Model and Empirical Evidence from India. Journal of Development Economics 88 (1): 103-119.

Bajpai, Nirupam and Jeffrey D. Sachs. 1999. The State of State government Finances in India. Harvard Institute for International Development. Development discussion paper no. 719. September.

Bagchi, Amaresh. 2003. Fifty Years of Fiscal Federalism in India. An Appraisal. Kale Memorial Lecture at Gokhale Institute of Politics and Economics, Pune.

Bandyopadhyay, Sangamitra. 2012. Convergence Club Empirics: Evidence from Indian States. Research in Economic Inequality 20: 175-203.

Bhattacharyya, B. B., and Sachidanandam Sakthivel. 2004. Regional Growth and Disparity in India: Comparison of Pre-and Post Reform Decades. Economic and Political Weekly 39 (10): 1071-1077.

Bird, Richard, and Francois Vaillancourt. 2007. Expenditure-Based Equalization Transfers. Fiscal Equalization. pp. 259-289.

Biswas, R., and S. Marjit. 2000. Political Lobbying and Discretionary Finance in India: An Aspect of Regional Political Influence in a Representative Democracy. Working Paper, Centre for Studies in Social Sciences, Calcutta.

Boadway Robin, and Anwar Shah. 2007. Intergovernmental Fiscal Transfers: Principles and Practice. Washington, DC: World Bank. 
Breitung, Jörg. 2000. The Local Power of Some Unit Root Tests for Panel Data. In Badi Baltagi, ed. Nonstationary Panels, Panel Cointegration, and Dynamic Panels. Advances in Econometrics. Vol. 15. Amsterdam: JAI.

Central Statistical Organization. 2010. Statistical Yearbook. Government of India.

Dasgupta, Sugato, Amrita Dhillon and Bhaskar Dutta. 2001. Electoral Goals and Centre-State Transfers in India. Working Paper, Indian Statistical Institute, New Delhi.

Denison, E. (1985). Trends in American Economic Growth, 1929-1982. Washington, D.C. Brookings Institutions.

Diewert, W. Erwin, and Kevin J. Fox. 2005. The New Economy and an Old Problem: Net versus Gross Output. CAER Working Paper. 2005/02.

Fischer, Stanley. 1993. The Role of Macroeconomic Factors in Growth. Journal of Monetary Economics 32 (3): 485-512.

George, Kumar Krishna. 2010. Liberalization for the Economy and Controls for the States. Twenty Years of Fiscal Federalism in India. CDS National Conference on the Indian Economy. 1-3 December.

Hadri, Kaddour. 2000. Testing for Stationarity in Heterogeneous Panel Data. Econometrics Journal 3 (2): 148-161.

Herd, Richard, and Willi Leibfritz. 2008. Fiscal Policy in India: Past Reforms and Future Challenges. OECD Economics Department Working Papers. No. 595. OECD Publishing.

Hulten, C. R. 1992. Accounting for the Wealth of Nations: The Net versus Gross Output Controversy and Its Ramifications. Scandinavian Journal of Economics. 94 (Supplement): 9-24.

Hulten, C. R. 2005. The "Architecture" of Capital Accounting: Basic Design Principles. Paper prepared for the Conference on Research in Income and Wealth, "A New Architecture for the U.S. National Accounts", April 16-17 2004.

Im, Kyung So, M Hashem Pesaran, and Yongcheol Shin. 2003. Testing for Unit Roots in Heterogeneous Panels. Journal of Econometrics 115 (1): 53-74.

Kao, Chihwa. 1999. Spurious Regression and Residual-based Tests for Cointegration in Panel Data. Journal of Econometrics 90 (1): pp. 1-44.

Kremers, Jeroen, Neil Ericsson, and Juan J. Dodado. 1992. The Power of Cointegration Tests. Oxford Bulletin of Economics and Statistics 54 (3): 325-348. 
Levin, Andrew, Chien Fu Lin, and Chia Shang Chu. 2002. Unit Root Tests in Panel Data: Asymptotic and Finite Sample Properties. Journal of Econometrics 108 (1): 1-24.

McCarten, William J 2001. The Challenge of Fiscal Discipline in the Indian States. In Jonathan Rodden, Gunnar Eskeland, and Jennie Litvack, eds. Decentralization and Hard Budget Constraints. MIT Press.

Ministry of Finance. 2007. Economic Survey 2008-09. New Delhi, Government of India.

Mohan, Rakesh. 1998. Financing of Sub-National Public Investment in India. National Council of Applied Economic Research, WP.

National Accounts Statistics. 2008. Manual on Estimation of State and District Income.

Nagaraj, Rayaprolu, Aristomène Varoudakis, and Marie Ange Vèganonès. 1998. Long-Run growth Trends and Convergence Across Indian States. OECD Development Centre, Working Paper No. 131.

Pedroni, Peter. 1999. Critical Values for Cointegrating Tests in Heterogeneous Panels with Multiple Regressors. Oxford Bulletin of Economics and Statistics 61 (1): 653-670.

Pedroni, Peter. 2004. Panel Cointegration: Asymptotic and Finite Sample Properties of Pooled Time Series Tests with an Application to the Purchasing Power Parity Hypothesis. Econometric Theory 20 (3): 597-625.

Persyn, Damiaan. and Joakim Westerlund. 2008. Error-Correction-Based Cointegration Tests for Panel Data. The Stata Journal 8 (2): 232-241.

Purfield, Catriona. 2006. Mind the Gap - Is Economic Growth in India Leaving Some States Behind? IMF Working Paper WP/06/103.

Ramalingom, R., and K.N. Kurup. 1991. Plan Transfers to States. Revised Gadgil Formula: An Analysis. Economic and Political Weekly 26 (9/10): 501-506.

Rao, Govinda. 1998. India: Intergovernmental Fiscal Relations in a Planned Economy. In Richard M. Bird and Francois Vaillancourt, eds. Fiscal Decentralization in Developing Countries. Cambridge, MA: Cambridge University Press.

- 2000. Fiscal Decentralization in Indian Federalism. Institute for Social and Economic Change. Bangalore.

_ 2002. State Finances in India: Issues and Challenges. Economic and Political Weekly 37 (31): $3261-3271$. 
- 2003. State Level Fiscal Reforms in India, paper presented at Cornell University, Conference on Indian Economic Reform, April 19-20.

- 2005. Changing Contours in Fiscal Federalism in India. National Institute of Public Finance and Policy. New Delhi.

- 2007. Fiscal Adjustment: Rhetoric and Reality. Economic and Political Weekly 42 (14): 1252-1257.

Rao, M. Govinda, and Nirvikar Singh. 2000. The Political Economy of Center-State Fiscal Transfers in India. Paper presented at the Columbia University-World Bank Conference on Institutional Elements of Tax Design and Reform, February 18-19.

Rao, M. Govinda, and Nirvikar Singh. 2001. India's Federal Institutions and Economic Reform. Paper presented at the conference on India's Public Institutions, Harvard University, February 9-10.

Rao, M. Govinda, and Nirvikar Singh. 2002. The Political Economy of Center-State Fiscal Transfers in India. In John McLaren (ed.), Institutional Elements of Tax Design and Reform. Washington DC, World Bank: 69-123.

Rao, Singh and Vashishta (2001)

Reserve Bank of India. Various issues. Handbook of Statistics on the Indian Economy and State Finances. Mumbai.

-Various issues. Report of the Twelfth Finance Commission. November. Mumbai.

- Various issues. States Finances: A Study of Budgets. Mumbai.

—. Various issues. Reserve Bank of India Bulletin. Union Budget - Review and Assessment. Mumbai.

THFC. 2010. Report of the Thirteenth Finance Commission (2010-2015). New Delhi.

Westerlund, Joakim. 2007. Testing for Error Correction in Panel Data. Oxford Bulletin of Economics and Statistics 69 (6): 709-748.

World Bank. 2009. World Development Report 2009: Reshaping Economic Geography, Oxford University Press, New York.

Zivot, Eric, and Donald Andrews. 1992. Further Evidence on the Great Crash, the Oil Price Shock, and the Unit Root Hypothesis. Journal of Business and Economic Statistics 10 (3): 25-44. 
Table A1: Variables used and Sources.

\begin{tabular}{|c|c|}
\hline Series & Sources \\
\hline NSDP (Per capita) current prices & $\begin{array}{l}\text { RBI Handbook of Statistics on } \\
\text { the Indian Economy, } 2010\end{array}$ \\
\hline GDP Deflator & IMF statistical database \\
\hline Plan Transfers & $\begin{array}{l}\text { Economic Survey of India- } \\
\text { Minstry of Finance (various } \\
\text { issues) }\end{array}$ \\
\hline $\begin{array}{l}\text { Non-plan transfers, Primary Deficit, } \\
\text { Macro controls (Social security } \\
\text { expenditure, Health expenditure, } \\
\text { education expenditure, size of } \\
\text { agricultural sector, size of industrial } \\
\text { sector, Interest payments, revenue } \\
\text { receipts) }\end{array}$ & $\begin{array}{l}\text { RBI Handbook of Statistics on } \\
\text { State Finances, } 2010\end{array}$ \\
\hline Gross Fiscal Deficit & $\begin{array}{l}\text { Central Statisical } \\
\text { Organization, NAS }\end{array}$ \\
\hline
\end{tabular}

\section{$\underline{\text { Notes }}$}

Each of these data series has been obtained for 24 states over the time period 1990-2010. While India has 28 states and 7 Union territories, due to the lack of availability of data for Bihar, Chhattisgarh, Jharkhand, Uttarakhand and the Union territories, these regions have been excluded from the analysis. 
Table 1. Net state domestic product, debt and fiscal transfers.

\begin{tabular}{|c|c|c|c|c|c|c|c|c|}
\hline States & \multicolumn{2}{|c|}{$\begin{array}{c}\text { Real NSDP Per capita } \\
\text { (Rupees) }\end{array}$} & \multicolumn{2}{|c|}{$\begin{array}{l}\text { Real State debt as } \\
\text { a \% of NSDP }\end{array}$} & \multicolumn{2}{|c|}{$\begin{array}{c}\text { Total non-plan } \\
\text { Transfers as \% of } \\
\text { NSDP }\end{array}$} & \multicolumn{2}{|c|}{$\begin{array}{c}\text { Total Transfers as } \\
\% \text { of NSDP }\end{array}$} \\
\hline $\begin{array}{c}\text { Non-Special Category } \\
\text { States } \\
\end{array}$ & 1990 & 2010 & 1990 & 2010 & 1990 & 2010 & 1990 & 2010 \\
\hline Goa & 25634.69 & 101287.47 & $2.40 \%$ & $27.59 \%$ & $7.58 \%$ & $2.40 \%$ & $10.24 \%$ & $4.15 \%$ \\
\hline Punjab & 23666.48 & 25979.91 & $2.11 \%$ & $52.54 \%$ & $1.74 \%$ & $3.84 \%$ & $2.14 \%$ & $4.88 \%$ \\
\hline Haryana & 21036.61 & 60123.48 & $3.46 \%$ & $13.35 \%$ & $1.99 \%$ & $1.39 \%$ & $2.30 \%$ & $1.83 \%$ \\
\hline Maharashtra & 19758.83 & 20859.03 & $1.54 \%$ & $47.10 \%$ & $2.38 \%$ & $5.13 \%$ & $2.74 \%$ & $7.27 \%$ \\
\hline Gujarat & 14966.56 & 48813.27 & $2.90 \%$ & $22.69 \%$ & $1.83 \%$ & $2.08 \%$ & $2.23 \%$ & $2.89 \%$ \\
\hline Karnataka & 14117.90 & 39758.99 & $3.69 \%$ & $14.67 \%$ & $3.43 \%$ & $3.23 \%$ & $3.94 \%$ & $3.81 \%$ \\
\hline Tamil Nadu & 13899.74 & 27320.81 & $4.88 \%$ & $26.09 \%$ & $4.10 \%$ & $4.88 \%$ & $4.89 \%$ & $5.90 \%$ \\
\hline Andhra Pradesh & 12928.82 & 38940.87 & $4.90 \%$ & $19.46 \%$ & $4.52 \%$ & $4.00 \%$ & $5.36 \%$ & $5.91 \%$ \\
\hline West Bengal & 12701.08 & 56734.23 & $3.28 \%$ & $19.63 \%$ & $3.59 \%$ & $2.41 \%$ & $4.87 \%$ & $2.83 \%$ \\
\hline Kerala & 12322.30 & 45163.78 & $7.62 \%$ & $22.04 \%$ & $4.96 \%$ & $3.08 \%$ & $5.71 \%$ & $3.96 \%$ \\
\hline Rajasthan & 10790.40 & 52453.60 & $6.10 \%$ & $12.19 \%$ & $6.35 \%$ & $2.79 \%$ & $8.14 \%$ & $3.27 \%$ \\
\hline Madhya Pradesh & 9965.72 & 20796.45 & $4.07 \%$ & $26.29 \%$ & $7.49 \%$ & $6.61 \%$ & $9.65 \%$ & $9.00 \%$ \\
\hline Uttar Pradesh & 9754.75 & 45472.86 & $6.44 \%$ & $10.65 \%$ & $6.34 \%$ & $3.61 \%$ & $8.13 \%$ & $4.01 \%$ \\
\hline Orissa & 9366.38 & 46359.67 & $8.82 \%$ & $7.83 \%$ & $8.96 \%$ & $4.97 \%$ & $10.52 \%$ & $6.48 \%$ \\
\hline mean & 15065.019 & 45004.601 & $4.44 \%$ & $23.01 \%$ & $4.66 \%$ & $3.60 \%$ & $5.78 \%$ & $4.73 \%$ \\
\hline \multicolumn{9}{|l|}{ Special Category States } \\
\hline Arunachal Pradesh & 15645.00 & 39230.87 & $4.96 \%$ & $23.99 \%$ & $30.21 \%$ & $18.05 \%$ & $55.78 \%$ & $46.15 \%$ \\
\hline Mizoram & 14242.56 & 37400.00 & $11.96 \%$ & $29.76 \%$ & $47.87 \%$ & $27.68 \%$ & $79.46 \%$ & $45.74 \%$ \\
\hline Sikkim & 13731.93 & 48497.31 & $21.05 \%$ & $42.86 \%$ & $10.82 \%$ & $22.91 \%$ & $52.19 \%$ & $42.02 \%$ \\
\hline Himachal Pradesh & 13643.23 & 38437.18 & $4.62 \%$ & $45.33 \%$ & $12.23 \%$ & $12.94 \%$ & $19.93 \%$ & $18.31 \%$ \\
\hline Nagaland & 13401.10 & 25357.16 & $28.54 \%$ & $58.03 \%$ & $38.51 \%$ & $27.25 \%$ & $55.09 \%$ & $47.62 \%$ \\
\hline Meghalaya & 11725.36 & 35092.19 & $4.15 \%$ & $16.88 \%$ & $18.23 \%$ & $11.36 \%$ & $34.36 \%$ & $22.89 \%$ \\
\hline Assam & 11226.72 & 20756.00 & $4.65 \%$ & $20.52 \%$ & $7.84 \%$ & $13.95 \%$ & $10.28 \%$ & $20.08 \%$ \\
\hline Manipur & 11171.58 & 33239.97 & $16.12 \%$ & $22.84 \%$ & $24.06 \%$ & $110.28 \%$ & $41.46 \%$ & $124.44 \%$ \\
\hline Jammu \& Kashmir & 9965.72 & 23339.34 & $13.72 \%$ & $43.19 \%$ & $21.11 \%$ & $16.43 \%$ & $28.40 \%$ & $31.24 \%$ \\
\hline Tripura & 8841.37 & 17854.42 & $13.47 \%$ & $33.95 \%$ & $28.95 \%$ & $25.54 \%$ & $44.35 \%$ & $42.08 \%$ \\
\hline mean & 12359.46 & 31920.44 & $12.32 \%$ & $33.74 \%$ & $23.98 \%$ & $28.64 \%$ & $42.13 \%$ & $44.06 \%$ \\
\hline mean (all states) & 13937.7 & 39552.87 & $7.73 \%$ & $27.48 \%$ & $12.71 \%$ & $14.03 \%$ & $20.92 \%$ & $21.12 \%$ \\
\hline
\end{tabular}


Table 2. Fiscal Deficit and Transfers: Correlation Coefficients (1990-2010).

\begin{tabular}{|l|c|c|}
\hline Variable & Plan transfers & Non-plan transfers \\
\hline Plan transfers & 1.000 & 0.629 \\
\hline Non-plan transfers & 0.629 & 1.000 \\
\hline Primary deficit & 0.132 & 0.333 \\
\hline Gross fiscal deficit & 0.361 & 0.679 \\
\hline
\end{tabular}


Table 3a. Panel Unit Root Tests (Levels)

\begin{tabular}{|l|c|c|c|c|c|c|}
\hline & $\begin{array}{c}\text { Levin, Lin } \\
\text { and Chu }\end{array}$ & $\begin{array}{c}\text { Breitung } \\
t \text {-stat }\end{array}$ & $\begin{array}{c}\text { Im, Pesaran } \\
\text { and Shin } \\
W \text {-stat }\end{array}$ & $\begin{array}{c}\text { ADF- } \\
\text { Fisher } \\
\text { Chi-square }\end{array}$ & $\begin{array}{c}\text { PP-Fisher } \\
\text { Chi-square }\end{array}$ & $\begin{array}{c}\text { Hadri } \\
z \text {-stat }\end{array}$ \\
\hline $\begin{array}{l}\text { NSDP per } \\
\text { capita }\end{array}$ & $\begin{array}{c}4.3545 \\
(1.0000)\end{array}$ & $\begin{array}{c}0.0048 \\
(0.5019)\end{array}$ & $\begin{array}{c}7.4230 \\
(1.0000)\end{array}$ & $\begin{array}{c}22.961 \\
(0.9992)\end{array}$ & $\begin{array}{c}41.814 \\
(0.7230)\end{array}$ & $\begin{array}{c}12.254 \\
(0.0000)\end{array}$ \\
\hline $\begin{array}{l}\text { Plan } \\
\text { transfers }\end{array}$ & 19.745 & -8.2835 & 18.957 & 0.2025 & 0.1357 & 13.011 \\
\hline $\begin{array}{l}\text { Non-plan } \\
\text { transfers }\end{array}$ & $(1.0000)$ & $(0.0000)$ & $(1.0000)$ & $(1.0000)$ & $(1.0000)$ & $(0.0000)$ \\
\hline $\begin{array}{l}\text { Primary } \\
\text { deficit }\end{array}$ & $1.0000)$ & -2.4522 & 11.961 & 2.2712 & 2.3951 & 11.786 \\
\hline $\begin{array}{l}\text { Gross fiscal } \\
\text { deficit }\end{array}$ & $(0.9012)$ & $(1.0000)$ & $(1.0000)$ & $(1.0000)$ & $(0.0000)$ \\
\hline
\end{tabular}

Table 3b. Panel Unit Root Tests (First Differences)

\begin{tabular}{|l|c|c|c|c|c|c|}
\hline & $\begin{array}{c}\text { Levin, Lin } \\
\text { and Chu }\end{array}$ & $\begin{array}{c}\text { Breitung } \\
t \text {-stat }\end{array}$ & $\begin{array}{c}\text { Im, Pesaran } \\
\text { and Shin } \\
W \text {-stat }\end{array}$ & $\begin{array}{c}\text { ADF - } \\
\text { Fisher } \\
\text { Chi-square }\end{array}$ & $\begin{array}{c}\text { PP-Fisher } \\
\text { Chi-square }\end{array}$ & $\begin{array}{c}\text { Hadri } \\
z \text {-stat }\end{array}$ \\
\hline $\begin{array}{l}\text { NSDP per } \\
\text { capita }\end{array}$ & -13.065 & -10.791 & -9.2213 & 167.00 & 190.12 & 4.6628 \\
& $(0.0000)$ & $(0.0000)$ & $(0.0001)$ & $(0.0003)$ & $(0.0000)$ & $(0.0000)$ \\
\hline Plan & -8.3063 & -7.9457 & -8.1446 & 203.90 & 486.35 & 4.6613 \\
transfers & $(0.0000)$ & $(0.0000)$ & $(0.0001)$ & $(0.0000)$ & $(0.0000)$ & $(0.0000)$ \\
\hline Non-plan & -11.850 & -10.845 & -9.7538 & 206.68 & 248.88 & 9.5853 \\
transfers & $(0.0000)$ & $(0.0000)$ & $(0.0000)$ & $(0.0000)$ & $(0.0000)$ & $(0.0000)$ \\
\hline $\begin{array}{l}\text { Primary } \\
\text { deficit }\end{array}$ & -16.054 & -12.584 & -15.508 & 295.36 & 366.52 & -0.4853 \\
\hline $\begin{array}{l}\text { Gross fiscal } \\
\text { deficit }\end{array}$ & $-15.0000)$ & $(0.0000)$ & $(0.0000)$ & $(0.0000)$ & $(0.0000)$ & $(0.6863)$ \\
\hline
\end{tabular}

Notes:

(i) The tests are computed on the panel data set.

(ii) All values reported in the table are the statistics values and $p$-values are in brackets.

(iii) The panel unit root tests reported in the table test for the existence of a unit root in the series, except the Hadri $z$-statistics. Hence, for all tests except the Hadri test, if the $t$-statistic falls within the rejection region and the $p$-value is low, the null hypothesis can be rejected and the series is stationary while the reverse would be true for the Hadri test. 
Table 4a. Summary Multi-variate Panel Cointegration (Pedroni Test).

\begin{tabular}{|c|c|c|c|c|c|c|c|}
\hline & $\begin{array}{l}\text { Pedroni } \\
\text { (group } \\
\text { rho- } \\
\text { statistic) }\end{array}$ & $\begin{array}{l}\text { Pedroni } \\
\text { (group } \\
\text { PP- } \\
\text { statistic) }\end{array}$ & $\begin{array}{l}\text { Pedroni } \\
\text { (group } \\
\text { ADF } \\
\text { statistic) }\end{array}$ & $\begin{array}{l}\text { Pedroni } \\
\text { (panel } \\
\text { v- } \\
\text { statistic) }\end{array}$ & $\begin{array}{l}\text { Pedroni } \\
\text { (panel } \\
\text { Rho- } \\
\text { statistic) }\end{array}$ & $\begin{array}{l}\text { Pedroni } \\
\text { (panel } \\
\text { PP- } \\
\text { statistic) }\end{array}$ & $\begin{array}{l}\text { Pedroni } \\
\text { (panel } \\
\text { ADF } \\
\text { statistic }\end{array}$ \\
\hline $\begin{array}{l}\text { NSDP per capita and } \\
\text { non-plan, plan transfers }\end{array}$ & $\begin{array}{c}1.5267 \\
(0.9366)\end{array}$ & $\begin{array}{l}-1.5396 \\
(0.0618)\end{array}$ & $\begin{array}{l}-4.5493 \\
(0.0075)\end{array}$ & $\begin{array}{l}-1.6470 \\
(0.9502)\end{array}$ & $\begin{array}{l}1.8603 \\
(0.9646)\end{array}$ & $\begin{array}{l}0.1614 \\
(0.5641)\end{array}$ & $\begin{array}{l}-0.0303 \\
(0.4879)\end{array}$ \\
\hline $\begin{array}{l}\text { Primary deficit and } \\
\text { non-plan, plan transfers }\end{array}$ & $\begin{array}{l}-0.1715 \\
(0.4319)\end{array}$ & $\begin{array}{l}-3.9969 \\
(0.0000)\end{array}$ & $\begin{array}{l}-3.5148 \\
(0.0002)\end{array}$ & $\begin{array}{c}2.9894 \\
(0.0014)\end{array}$ & $\begin{array}{l}-0.8944 \\
(0.1855)\end{array}$ & $\begin{array}{r}-2.2193 \\
(0.0132)\end{array}$ & $\begin{array}{l}-3.4871 \\
(0.0001)\end{array}$ \\
\hline $\begin{array}{l}\text { Gross fiscal deficit and } \\
\text { non- plan, plan transfers }\end{array}$ & $\begin{array}{c}1.3390 \\
(0.9097)\end{array}$ & $\begin{array}{l}-2.4733 \\
(0.0067)\end{array}$ & $\begin{array}{l}-4.9851 \\
(0.0000)\end{array}$ & $\begin{array}{c}1.1258 \\
(0.1301)\end{array}$ & $\begin{array}{l}-0.0091 \\
(0.4963)\end{array}$ & $\begin{array}{l}-1.1792 \\
(0.1192)\end{array}$ & $\begin{array}{l}-1.6783 \\
(0.0466)\end{array}$ \\
\hline $\begin{array}{c}\text { NSDP per capita, } \\
\text { primary deficit, total } \\
\text { transfers } \\
\text { (plan, non plan) }\end{array}$ & $\begin{array}{l}-2.5067 \\
(0.0061)\end{array}$ & $\begin{array}{l}-5.7185 \\
(0.0000)\end{array}$ & $\begin{array}{l}1.4531 \\
(0.9269)\end{array}$ & $\begin{array}{c}2.1301 \\
(0.0126)\end{array}$ & $\begin{array}{l}-0.7083 \\
(0.0011)\end{array}$ & $\begin{array}{l}-0.9337 \\
(0.0000)\end{array}$ & $\begin{array}{l}4.4445 \\
(0.7759)\end{array}$ \\
\hline $\begin{array}{c}\text { NSDP per capita, gross } \\
\text { fiscal deficit, total } \\
\text { transfers (plan, non- } \\
\text { plan) }\end{array}$ & $\begin{array}{l}-1.5048 \\
(0.0662)\end{array}$ & $\begin{array}{l}-3.7004 \\
(0.0001)\end{array}$ & $\begin{array}{l}1.6900 \\
(0.9545)\end{array}$ & $\begin{array}{r}2.1472 \\
(0.0159)\end{array}$ & $\begin{array}{l}-1.2653 \\
(0.1029)\end{array}$ & $\begin{array}{l}-2.2124 \\
(0.0135)\end{array}$ & $\begin{array}{l}1.6621 \\
(0.9518)\end{array}$ \\
\hline $\begin{array}{l}\text { NSDP per capita, } \\
\text { primary deficit, gross } \\
\text { fiscal deficit and total } \\
\text { transfers (plan, non- } \\
\text { plan) } \\
\end{array}$ & $\begin{array}{l}-2.1818 \\
(0.0146)\end{array}$ & $\begin{array}{l}-8.6782 \\
(0.0000)\end{array}$ & $\begin{array}{c}0.0853 \\
(0.5340)\end{array}$ & $\begin{array}{c}1.9502 \\
(0.0256)\end{array}$ & $\begin{array}{l}-2.3535 \\
(0.0093)\end{array}$ & $\begin{array}{l}-5.8803 \\
(0.0000)\end{array}$ & $\begin{array}{l}0.3126 \\
(0.6227)\end{array}$ \\
\hline
\end{tabular}

\footnotetext{
${ }^{4}$ Fischer $(r<3)$ is only applicable to this set of variables. The corresponding $p$-value is 0.0736 .
} 
Table 4b. Summary Multi-variate Panel Cointegration.

\begin{tabular}{|c|c|c|c|c|c|}
\hline & $\begin{array}{l}\text { Fischer } \\
(r<0)\end{array}$ & $\begin{array}{l}\text { Fischer } \\
(\mathrm{r}<1)\end{array}$ & $\begin{array}{l}\text { Fischer } \\
(\mathrm{r}<2)\end{array}$ & $\begin{array}{l}\text { Kao } \\
(1999)\end{array}$ & $\begin{array}{l}\text { Cointegr. } \\
\text { coeff. } \\
\text { (Kao) }\end{array}$ \\
\hline $\begin{array}{l}\text { NSDP per capita and } \\
\text { non-plan, plan transfers }\end{array}$ & $\begin{array}{c}213.3 \\
(0.0000)\end{array}$ & $\begin{array}{c}100.3 \\
(0.0015)\end{array}$ & $\begin{array}{c}88.05 \\
(0.0004)\end{array}$ & $\begin{array}{c}1.8568 \\
(0.0155)\end{array}$ & -0.0738 \\
\hline $\begin{array}{c}\text { Primary deficit and } \\
\text { non-plan, plan transfers }\end{array}$ & $\begin{array}{c}210.5 \\
(0.0000)\end{array}$ & $\begin{array}{c}72.47 \\
(0.0803)\end{array}$ & $\begin{array}{c}58.93 \\
(0.1341)\end{array}$ & $\begin{array}{l}-7.5186 \\
(0.0000)\end{array}$ & 0.1304 \\
\hline $\begin{array}{l}\text { Gross fiscal deficit and } \\
\text { non- plan, plan transfers }\end{array}$ & $\begin{array}{c}205.6 \\
(0.0000)\end{array}$ & $\begin{array}{c}65.48 \\
(0.0008)\end{array}$ & $\begin{array}{c}59.41 \\
(0.0076)\end{array}$ & $\begin{array}{l}-4.9031 \\
(0.0000)\end{array}$ & 0.2070 \\
\hline $\begin{array}{l}\text { NSDP per capita, primary } \\
\text { deficit, total transfers } \\
\text { (plan, non plan) }\end{array}$ & $\begin{array}{c}223.7 \\
(0.0000)\end{array}$ & $\begin{array}{c}90.99 \\
(0.0000)\end{array}$ & $\begin{array}{c}91.38 \\
(0.0000)\end{array}$ & $\begin{array}{r}5.3610 \\
(0.0000)\end{array}$ & -0.0481 \\
\hline $\begin{array}{l}\text { NSDP per capita, gross } \\
\text { fiscal deficit, total } \\
\text { transfers (plan, non-plan) }\end{array}$ & $\begin{array}{c}132.0 \\
(0.0000)\end{array}$ & $\begin{array}{c}59.13 \\
(0.0416)\end{array}$ & $\begin{array}{c}73.40 \\
(0.0019)\end{array}$ & $\begin{array}{c}5.0484 \\
(0.0008)\end{array}$ & -0.0504 \\
\hline $\begin{array}{c}\text { NSDP per capita, primary } \\
\text { deficit, gross fiscal deficit } \\
\text { and total transfers (plan, } \\
\text { non-plan) }\end{array}$ & $\begin{array}{c}298.2 \\
(0.0000)\end{array}$ & $\begin{array}{c}88.81 \\
(0.0000)\end{array}$ & $\begin{array}{c}59.54 \\
(0.0385)\end{array}$ & $\begin{array}{c}5.3996 \\
(0.0006)\end{array}$ & -0.0494 \\
\hline
\end{tabular}

Notes:

i) Tables $4 \mathrm{a}$ and $4 \mathrm{~b}$ consist of two sets of analysis.

ii) The first three rows deal with the cointegration between transfers which has been further divided into plan and non-plan transfers with NSDP per capita and gross, primary deficit respectively. The dependent variable is the first variable in column 1.

iii) The last three rows consist of cointegration analysis between aggregate transfers and other variables.

The dependent variable is aggregate transfers and the long run relationship with both deficits (together and separately) and NSDP per capita is analyzed.

iv) From the Kao (1999) tests we can also obtain the cointegration coefficients (for first differences) which confirm the positive relationship between transfers and the primary deficit and gross fiscal deficit respectively.

\footnotetext{
${ }^{5}$ Fischer $(r<3)$ is only applicable to this set of variables. The corresponding $p$-value $: 0.0003, \mathrm{t}$ stat 81.08 .
} 
Table 4c. Summary Multi-variate Panel Cointegration (Pedroni Test) (by state income).

\begin{tabular}{|c|c|c|c|c|c|c|c|}
\hline & $\begin{array}{l}\text { Pedroni } \\
\text { (group } \\
\text { rho- } \\
\text { statistic) }\end{array}$ & $\begin{array}{l}\begin{array}{l}\text { Pedroni } \\
\text { (group }\end{array} \\
\text { PP- } \\
\text { statistic) }\end{array}$ & $\begin{array}{l}\text { Pedroni } \\
\text { (group } \\
\text { ADF } \\
\text { statistic) }\end{array}$ & $\begin{array}{l}\text { Pedroni } \\
\text { (panel } \\
\text { v- } \\
\text { statistic) }\end{array}$ & $\begin{array}{l}\begin{array}{l}\text { Pedroni } \\
\text { (panel }\end{array} \\
\text { Rho- } \\
\text { statistic) }\end{array}$ & $\begin{array}{l}\begin{array}{l}\text { Pedroni } \\
\text { (panel }\end{array} \\
\text { PP- } \\
\text { statistic) }\end{array}$ & $\begin{array}{l}\text { Pedroni } \\
\text { (panel } \\
\text { ADF-statistic) }\end{array}$ \\
\hline \multicolumn{8}{|c|}{ Rich States } \\
\hline $\begin{array}{l}\text { NSDP per capita, } \\
\text { primary deficit, } \\
\text { gross fiscal deficit } \\
\text { and total transfers } \\
\text { (plan, non-plan) }\end{array}$ & $\begin{array}{l}1.997 \\
(0.9771)\end{array}$ & $\begin{array}{l}2.8247 \\
(0.9976)\end{array}$ & $\begin{array}{l}4.1624 \\
(1.0000)\end{array}$ & $\begin{array}{l}-0.5799 \\
(0.7190)\end{array}$ & $\begin{array}{l}1.0962 \\
(0.8635)\end{array}$ & $\begin{array}{l}1.5076 \\
(0.9342)\end{array}$ & $\begin{array}{c}2.6417 \\
(0.9959)\end{array}$ \\
\hline \multicolumn{8}{|c|}{ Middle Income states } \\
\hline $\begin{array}{l}\text { NSDP per capita, } \\
\text { primary deficit, } \\
\text { gross fiscal deficit } \\
\text { and total transfers } \\
\text { (plan, non-plan) }\end{array}$ & $\begin{array}{l}2.2606 \\
(0.9881)\end{array}$ & $\begin{array}{l}1.2885 \\
(0.9012)\end{array}$ & $\begin{array}{l}-0.6387 \\
(0.2615)\end{array}$ & $\begin{array}{l}0.5706 \\
(0.2841)\end{array}$ & $\begin{array}{l}0.8324 \\
(0.7974)\end{array}$ & $\begin{array}{l}0.5391 \\
(0.7051)\end{array}$ & $\begin{array}{c}0.0093 \\
(0.5037)\end{array}$ \\
\hline \multicolumn{8}{|c|}{ Low Income States } \\
\hline $\begin{array}{l}\text { NSDP per capita, } \\
\text { primary deficit, } \\
\text { gross fiscal deficit } \\
\text { and total transfers } \\
\text { (plan, non-plan) }\end{array}$ & $\begin{array}{l}2.2712 \\
(0.9884)\end{array}$ & $\begin{array}{l}2.7163 \\
(0.9967)\end{array}$ & $\begin{array}{l}2.0799 \\
(0.9812)\end{array}$ & $\begin{array}{l}2.1610 \\
(0.0153)\end{array}$ & $\begin{array}{l}1.5225 \\
(0.9361)\end{array}$ & $\begin{array}{l}2.6078 \\
(0.9954)\end{array}$ & $\begin{array}{c}2.6348 \\
(0.9958)\end{array}$ \\
\hline
\end{tabular}

Table 4d. Summary Multi-variate Panel Cointegration (by state income).

\begin{tabular}{|c|c|c|c|c|c|}
\hline & $\begin{array}{c}\text { Fischer } \\
(\mathrm{r}<0)\end{array}$ & $\begin{array}{c}\begin{array}{c}\text { Fischer } \\
(\mathrm{r}<1)\end{array} \\
\text { ( }\end{array}$ & $\begin{array}{c}\begin{array}{c}\text { Fischer } \\
(\mathrm{r}<2)\end{array} \\
\text { ( }\end{array}$ & $\begin{array}{c}\text { Fischer } \\
(\mathrm{r}<3)\end{array}$ & $\begin{array}{c}\text { Kao } \\
(1999)\end{array}$ \\
\hline \multicolumn{6}{|c|}{ Rich States } \\
\hline $\begin{array}{l}\text { NSDP per capita, primary } \\
\text { deficit, gross fiscal deficit } \\
\text { and total transfers (plan, } \\
\text { non-plan) }\end{array}$ & $\begin{array}{l}44.24 \\
(0.0000)\end{array}$ & $\begin{array}{l}23.99 \\
(0.0023)\end{array}$ & $\begin{array}{l}9.7777 \\
(0.2810)\end{array}$ & $\begin{array}{l}10.40 \\
(0.2380)\end{array}$ & $\begin{array}{c}2.4308 \\
(0.0075)\end{array}$ \\
\hline \multicolumn{6}{|c|}{ Middle Income states } \\
\hline $\begin{array}{c}\text { NSDP per capita, primary } \\
\text { deficit, gross fiscal deficit } \\
\text { and total transfers (plan, } \\
\text { non-plan) }\end{array}$ & $\begin{array}{l}121.5 \\
(0.0000)\end{array}$ & $\begin{array}{l}53.18 \\
(0.0002)\end{array}$ & $\begin{array}{l}22.69 \\
(0.4193)\end{array}$ & $\begin{array}{l}46.93 \\
(0.0015)\end{array}$ & $\begin{array}{c}1.6827 \\
(0.0462)\end{array}$ \\
\hline \multicolumn{6}{|c|}{ Low Income States } \\
\hline $\begin{array}{l}\text { NSDP per capita, primary } \\
\text { deficit, gross fiscal deficit } \\
\text { and total transfers (plan, } \\
\text { non-plan) }\end{array}$ & $\begin{array}{l}141.8 \\
(0.0000)\end{array}$ & $\begin{array}{l}55.54 \\
(0.0000)\end{array}$ & $\begin{array}{l}24.92 \\
(0.1271)\end{array}$ & $\begin{array}{l}30.31 \\
(0.0345)\end{array}$ & $\begin{array}{c}1.9823 \\
(0.0237)\end{array}$ \\
\hline
\end{tabular}


Table 4e. Summary Multi-variate Panel Cointegration by Special Category Status (Pedroni Test).

\begin{tabular}{|c|c|c|c|c|c|c|c|}
\hline & $\begin{array}{l}\text { Pedroni } \\
\text { (group } \\
\text { rho- } \\
\text { statistic) }\end{array}$ & $\begin{array}{l}\begin{array}{l}\text { Pedroni } \\
\text { (group }\end{array} \\
\text { PP- } \\
\text { statistic) }\end{array}$ & $\begin{array}{l}\text { Pedroni } \\
\text { (group } \\
\text { ADF } \\
\text { statistic) }\end{array}$ & $\begin{array}{l}\text { Pedroni } \\
\text { (panel } \\
\text { v- } \\
\text { statistic) }\end{array}$ & $\begin{array}{l}\text { Pedroni } \\
\text { (panel } \\
\text { Rho- } \\
\text { statistic) }\end{array}$ & $\begin{array}{l}\text { Pedroni } \\
\text { (panel } \\
\text { PP- } \\
\text { statistic) }\end{array}$ & $\begin{array}{l}\text { Pedroni } \\
\text { (panel } \\
\text { ADF-statistic) }\end{array}$ \\
\hline \multicolumn{8}{|c|}{ Special Category States } \\
\hline $\begin{array}{l}\text { NSDP per capita, } \\
\text { primary deficit, } \\
\text { gross fiscal deficit } \\
\text { and total transfers } \\
\text { (plan, non-plan) }\end{array}$ & $\begin{array}{l}1.4969 \\
(0.9328)\end{array}$ & $\begin{array}{l}-1.0406 \\
(0.1490)\end{array}$ & $\begin{array}{l}-0.2339 \\
(0.4075)\end{array}$ & $\begin{array}{l}-0.2916 \\
(0.6147)\end{array}$ & $\begin{array}{l}0.6809 \\
(0.7521)\end{array}$ & $\begin{array}{l}-0.4888 \\
(0.3125)\end{array}$ & $\begin{array}{c}0.2127 \\
(0.5842)\end{array}$ \\
\hline \multicolumn{8}{|c|}{ Non-special Category States } \\
\hline $\begin{array}{l}\text { NSDP per capita, } \\
\text { primary deficit, } \\
\text { gross fiscal deficit } \\
\text { and total transfers } \\
\text { (plan, non-plan) }\end{array}$ & $\begin{array}{l}3.4173 \\
(0.9997)\end{array}$ & $\begin{array}{l}3.5792 \\
(0.9998)\end{array}$ & $\begin{array}{l}1.0442 \\
(0.8518)\end{array}$ & $\begin{array}{l}0.4919 \\
(0.3114)\end{array}$ & $\begin{array}{l}1.7313 \\
(0.9583)\end{array}$ & $\begin{array}{l}1.8785 \\
(0.9698)\end{array}$ & $\begin{array}{r}0.8404 \\
(0.7997)\end{array}$ \\
\hline
\end{tabular}

Table 4f. Summary Multi-variate Panel Cointegration by Special Category Status (Fischer \& Kao Tests).

\begin{tabular}{|c|l|l|l|l|c|}
\hline & $\begin{array}{r}\text { Fischer } \\
(\mathrm{r}<0)\end{array}$ & $\begin{array}{c}\text { Fischer } \\
(\mathrm{r}<1)\end{array}$ & $\begin{array}{c}\text { Fischer } \\
(\mathrm{r}<2)\end{array}$ & $\begin{array}{c}\text { Fischer } \\
(\mathrm{r}<3)\end{array}$ & $\begin{array}{c}\text { Kao } \\
(1999)\end{array}$ \\
\hline \multicolumn{6}{|c|}{ Special Category States } \\
\hline $\begin{array}{c}\text { NSDP per capita, primary } \\
\text { deficit, gross fiscal deficit } \\
\text { and total transfers (plan, } \\
\text { non-plan) }\end{array}$ & $\begin{array}{l}128.5 \\
(0.0000)\end{array}$ & $\begin{array}{l}39.07 \\
(0.0065)\end{array}$ & $\begin{array}{l}21.94 \\
(0.3439)\end{array}$ & $\begin{array}{l}28.42 \\
(0.1042)\end{array}$ & $\begin{array}{c}1.2639 \\
(0.1031)\end{array}$ \\
\hline \multicolumn{7}{|c|}{ Non-special Category States } \\
\hline $\begin{array}{c}\text { NSDP per capita, primary } \\
\text { deficit, gross fiscal deficit } \\
\text { and total transfers (plan, } \\
\text { non-plan) }\end{array}$ & 179.1 & $\begin{array}{l}93.64 \\
(0.0000)\end{array}$ & $\begin{array}{l}35.45 \\
(0.1571)\end{array}$ & $\begin{array}{l}59.41 \\
(0.0005)\end{array}$ & $\begin{array}{c}5.1542 \\
(0.0000)\end{array}$ \\
\hline
\end{tabular}

Notes:

i) The dependent variable is total transfers.

ii) The values reported in the table are $t$-statistics ( $p$-values in brackets).

iii) The null hypothesis is that of no cointegration. Hence a low $p$-value is indicative of cointegration. 
Table 5. Bi-variate Granger Causality Tests.

\begin{tabular}{|c|c|c|c|c|c|}
\hline \multirow[t]{2}{*}{ Explanatory variable } & \multicolumn{5}{|c|}{ Dependent variable } \\
\hline & Non-plan transfers & Plan transfers & $\begin{array}{l}\text { NSDP } \\
\text { per capita }\end{array}$ & $\begin{array}{l}\text { Primary } \\
\text { deficit }\end{array}$ & $\begin{array}{l}\text { Gross fiscal } \\
\text { deficit }\end{array}$ \\
\hline Non-plan transfers & ---- & ---- & $\begin{array}{c}1.88497 \\
(0.1531)\end{array}$ & $\begin{array}{c}21.201 \\
(0.0000)\end{array}$ & $\begin{array}{c}5.39855 \\
(0.0003)\end{array}$ \\
\hline Plan transfers & ---- & ---- & $\begin{array}{c}0.3732 \\
(0.96337)\end{array}$ & $\begin{array}{c}2.63024 \\
(0.02371)\end{array}$ & $\begin{array}{l}3.25196 \\
(0.0122)\end{array}$ \\
\hline NSDP per capita & $\begin{array}{r}3.22828 \\
(0.04065)\end{array}$ & $\begin{array}{l}4.23860 \\
(0.0150)\end{array}$ & ---- & ---- & ---- \\
\hline Primary deficit & $\begin{array}{c}6.9188 \\
(0.0011)\end{array}$ & $\begin{array}{l}4.03218 \\
(0.0014)\end{array}$ & ---- & ---- & ---- \\
\hline Gross fiscal deficit & $\begin{array}{c}5.53886 \\
(0.0002)\end{array}$ & $\begin{array}{l}5.77177 \\
(0.0002)\end{array}$ & ---- & ---- & ---- \\
\hline
\end{tabular}

Notes:

(i) The values reported in the table are $F$-statistics.

(ii) The figures in brackets are $p$-values. 
Table 6. ECM-based Bi-variate Cointegration Tests.

\begin{tabular}{|l|c|c|c|c|c|c|c|c|}
\hline & $G_{\tau}$ & $G_{\alpha}$ & $P_{\tau}$ & $P_{\alpha}$ & $G_{\tau}(B)$ & $G_{\alpha}(B)$ & $P_{\tau}(B)$ & $P_{\alpha}(B)$ \\
\hline NSDP per capita and non-plan & $\begin{array}{c}-2.538 \\
\text { transfers }\end{array}$ & $\begin{array}{c}0.692 \\
(0.006)\end{array}$ & $\begin{array}{c}-7.107 \\
(0.756)\end{array}$ & $\begin{array}{c}-3.249 \\
(0.000)\end{array}$ & $\begin{array}{c}-9.674 \\
(0.090)\end{array}$ & $\begin{array}{c}-9.574 \\
(0.040)\end{array}$ & $\begin{array}{c}-16.07 \\
(0.000)\end{array}$ & $\begin{array}{l}-16.18 \\
(0.010)\end{array}$ \\
\hline $\begin{array}{l}\text { Primary deficit and non-plan } \\
\text { transfers }\end{array}$ & -1.673 & -0.322 & -3.328 & -2.951 & -2.330 & -4.455 & -4.363 & -6.643 \\
$(0.047)$ & $(0.374)$ & $(0.000)$ & $(0.000)$ & $(0.010)$ & $(0.000)$ & $(0.000)$ & $(0.000)$ \\
\hline $\begin{array}{l}\text { Gross fiscal deficit and non-plan } \\
\text { transfers }\end{array}$ & $\begin{array}{c}1.880 \\
(1.000)\end{array}$ & $\begin{array}{c}3.066 \\
(1.0000)\end{array}$ & $\begin{array}{c}-2.395 \\
(0.008)\end{array}$ & $\begin{array}{c}-0.322 \\
(0.374)\end{array}$ & $\begin{array}{c}-4.506 \\
(0.000)\end{array}$ & $\begin{array}{c}-4.258 \\
(0.000)\end{array}$ & $\begin{array}{c}-3.328 \\
(0.000)\end{array}$ & $\begin{array}{c}-5.713 \\
(0.000)\end{array}$ \\
\hline $\begin{array}{l}\text { NSDP per capita and plan } \\
\text { transfers }\end{array}$ & $\begin{array}{c}-9.834 \\
(0.0000)\end{array}$ & $\begin{array}{c}-0.112 \\
(0.455)\end{array}$ & $\begin{array}{c}-9.258 \\
(0.000)\end{array}$ & $\begin{array}{c}-2.617 \\
(0.004)\end{array}$ & $\begin{array}{c}-9.674 \\
(0.040)\end{array}$ & $\begin{array}{c}-9.574 \\
(0.000)\end{array}$ & $\begin{array}{c}-16.07 \\
(0.000)\end{array}$ & $\begin{array}{c}-16.18 \\
(0.000)\end{array}$ \\
\hline $\begin{array}{l}\text { Primary deficit and plan } \\
\text { transfers }\end{array}$ & $\begin{array}{c}-3.367 \\
(0.000)\end{array}$ & $\begin{array}{c}-2.372 \\
(0.009)\end{array}$ & $\begin{array}{c}-4.553 \\
(0.000)\end{array}$ & $\begin{array}{c}-4.377 \\
(0.000)\end{array}$ & $\begin{array}{c}7.402 \\
(1.000)\end{array}$ & $\begin{array}{c}5.144 \\
(1.000)\end{array}$ & $\begin{array}{c}4.724 \\
(0.990)\end{array}$ & $\begin{array}{c}-0.198 \\
(0.890)\end{array}$ \\
\hline $\begin{array}{l}\text { Gross fiscal deficit and plan } \\
\text { transfers }\end{array}$ & $\begin{array}{c}-7.971 \\
(0.000)\end{array}$ & $\begin{array}{c}0.541 \\
(0.706)\end{array}$ & $\begin{array}{c}-7.552 \\
(0.000)\end{array}$ & $\begin{array}{c}-1.303 \\
(0.096)\end{array}$ & $\begin{array}{c}8.529 \\
(1.000)\end{array}$ & $\begin{array}{c}4.242 \\
(1.000)\end{array}$ & $\begin{array}{c}9.328 \\
(1.000)\end{array}$ & $\begin{array}{c}4.669 \\
(1.000)\end{array}$ \\
\hline
\end{tabular}

Notes:

(i) The figures reported in the table are $p$-values.

(ii) For $G_{\tau}, G_{\alpha}, P_{\tau}$, and $P_{\alpha}$ the $p$-values are for a one-sided test based on the standard normal distribution.

(iii) For $G_{\tau}(B), G_{\alpha}(B), P_{\tau}(B)$, and $P_{\alpha}(B)$ the $p$-values are for a one-sided test based on a bootstrapped distribution.

(iv) The second variable in column 1 is the dependent variable. 
Table 7. ECM-based Multi-variate Cointegration Tests.

\begin{tabular}{|c|c|c|c|c|c|c|c|c|}
\hline & $G_{\tau}$ & $G_{\alpha}$ & $P_{\tau}$ & $P_{\alpha}$ & $G_{\tau}(B)$ & $G_{\alpha}(B)$ & $P_{\tau}(B)$ & $P_{\alpha}(B)$ \\
\hline $\begin{array}{l}\text { NSDP per capita and non- } \\
\text { plan, plan transfers }\end{array}$ & $\begin{array}{c}1.983 \\
(0.976)\end{array}$ & $\begin{array}{c}4.170 \\
(1.000)\end{array}$ & $\begin{array}{c}0.512 \\
(0.696)\end{array}$ & $\begin{array}{l}2.243 \\
(0.988)\end{array}$ & $\begin{array}{l}-2.249 \\
(0.010)\end{array}$ & $\begin{array}{l}-0.601 \\
(0.000)\end{array}$ & $\begin{array}{l}-4.104 \\
(0.000)\end{array}$ & $\begin{array}{l}-3.386 \\
(0.000)\end{array}$ \\
\hline $\begin{array}{l}\text { Primary deficit and non-plan, } \\
\text { plan transfers }\end{array}$ & $\begin{array}{l}-2.357 \\
(0.841)\end{array}$ & $\begin{array}{l}-9.982 \\
(0.993)\end{array}$ & $\begin{array}{l}-13.32 \\
(0.009)\end{array}$ & $\begin{array}{l}-9.932 \\
(0.656)\end{array}$ & $\begin{array}{l}-0.150 \\
(0.240)\end{array}$ & $\begin{array}{c}0.838 \\
(0.090)\end{array}$ & $\begin{array}{l}-2.960 \\
(0.020)\end{array}$ & $\begin{array}{l}-2.611 \\
(0.020)\end{array}$ \\
\hline $\begin{array}{l}\text { Gross fiscal deficit and non- } \\
\text { plan, plan transfers }\end{array}$ & $\begin{array}{l}-2.502 \\
(0.562)\end{array}$ & $\begin{array}{l}-9.512 \\
(0.997\end{array}$ & $\begin{array}{l}-14.29 \\
(0.000)\end{array}$ & $\begin{array}{l}-10.84 \\
(0.397)\end{array}$ & $\begin{array}{l}-0.630 \\
(0.080)\end{array}$ & $\begin{array}{c}0.874 \\
(0.090)\end{array}$ & $\begin{array}{l}-3.735 \\
(0.030)\end{array}$ & $\begin{array}{l}-3.069 \\
(0.030)\end{array}$ \\
\hline $\begin{array}{l}\text { NSDP per capita, primary } \\
\text { deficit, total transfers (plan, } \\
\text { non-plan) }\end{array}$ & $\begin{array}{l}5.550 \\
(0.998)\end{array}$ & $\begin{array}{c}7.420 \\
(1.000)\end{array}$ & $\begin{array}{c}7.045 \\
(1.000)\end{array}$ & $\begin{array}{c}5.424 \\
(1.000)\end{array}$ & $\begin{array}{l}-0.63 \\
(0.430)\end{array}$ & $\begin{array}{l}2.14 \\
(0.030)\end{array}$ & $\begin{array}{l}1.88 \\
(0.06)\end{array}$ & $\begin{array}{l}2.14 \\
(0.030)\end{array}$ \\
\hline $\begin{array}{l}\text { NSDP per capita, gross fiscal } \\
\text { deficit, total transfers (plan, } \\
\text { non-plan) }\end{array}$ & $\begin{array}{l}4.765 \\
(0.955)\end{array}$ & $\begin{array}{c}7.119 \\
(1.000)\end{array}$ & $\begin{array}{l}5.737 \\
(1.000)\end{array}$ & $\begin{array}{l}5.306 \\
(1.000)\end{array}$ & $\begin{array}{l}3.020 \\
(0.870)\end{array}$ & $\begin{array}{l}3.503 \\
(0.860)\end{array}$ & $\begin{array}{l}2.648 \\
(0.740)\end{array}$ & $\begin{array}{l}1.989 \\
(0.690)\end{array}$ \\
\hline $\begin{array}{l}\text { NSDP per capita, primary } \\
\text { deficit, gross fiscal deficit and } \\
\text { total transfers (plan, non-plan) }\end{array}$ & $\begin{array}{c}4.777 \\
(1.000)\end{array}$ & $\begin{array}{c}5.664 \\
(1.000)\end{array}$ & $\begin{array}{l}3.823 \\
(1.000)\end{array}$ & $\begin{array}{l}3.145 \\
(1.000)\end{array}$ & $\begin{array}{l}3.685 \\
(0.740)\end{array}$ & $\begin{array}{l}5.708 \\
(0.880)\end{array}$ & $\begin{array}{l}3.963 \\
(0.840)\end{array}$ & $\begin{array}{c}3.123 \\
(0.790)\end{array}$ \\
\hline $\begin{array}{l}\text { NSDP per capita, primary } \\
\text { deficit, debt and non-plan } \\
\text { transfers }\end{array}$ & $\begin{array}{c}0.732 \\
(0.768)\end{array}$ & $\begin{array}{c}3.693 \\
(1.000)\end{array}$ & $\begin{array}{l}-2.633 \\
(0.004)\end{array}$ & $\begin{array}{c}0.911 \\
(0.819)\end{array}$ & $\begin{array}{l}-1.848 \\
(0.060)\end{array}$ & $\begin{array}{c}0.866 \\
(0.040)\end{array}$ & $\begin{array}{l}-3.962 \\
(0.020)\end{array}$ & $\begin{array}{l}-2.231 \\
(0.010)\end{array}$ \\
\hline $\begin{array}{l}\text { NSDP per capita, primary } \\
\text { deficit, debt and plan transfers }\end{array}$ & $\begin{array}{l}-3.377 \\
(0.000)\end{array}$ & $\begin{array}{l}-10.59 \\
(0.999)\end{array}$ & $\begin{array}{l}-17.07 \\
(0.000)\end{array}$ & $\begin{array}{l}-11.05 \\
(0.764)\end{array}$ & $\begin{array}{l}-6.082 \\
(0.000)\end{array}$ & $\begin{array}{l}-1.001 \\
(0.000)\end{array}$ & $\begin{array}{l}-6.255 \\
(0.000)\end{array}$ & $\begin{array}{l}-3.536 \\
(0.000)\end{array}$ \\
\hline
\end{tabular}

Notes:

(i) Sample period is 1990-2010.

(ii) The figures reported in the table are $p$-values.

(iii) For $G_{\tau}, G_{\alpha}, P_{\tau}$, and $P_{\alpha}$ the $p$-values are for a one-sided test based on the standard normal distribution.

(iv) For $G_{\tau}(B), G_{\alpha}(B), P_{\tau}(B)$, and $P_{\alpha}(B)$ the $p$-values are for a one-sided test based on a bootstrapped distribution.

(v) The dependent variable in the rows 4, 5,6, 7 and 8 is the last variable in column 1.

(vi) In rows 1,2 and 3 the first variable is the dependent variable. 
Table 8. ECM-based Multi-variate Cointegration Tests: 1981-2010.

\begin{tabular}{|l|l|l|l|l|l|l|l|l|}
\hline & \multicolumn{1}{|c|}{$G_{\tau}$} & $G_{\alpha}$ & $P_{\tau}$ & \multicolumn{1}{|c|}{$P_{\alpha}$} & $G_{\tau}(B)$ & $G_{\alpha}(B)$ & $P_{\tau}(B)$ & $P_{\alpha}(B)$ \\
\hline $\begin{array}{l}\text { NSDP per capita, primary deficit } \\
\text { and total transfers }\end{array}$ & $\begin{array}{l}-0.605 \\
(0.273)\end{array}$ & $\begin{array}{l}1.819 \\
(0.966)\end{array}$ & $\begin{array}{l}-0.761 \\
(0.224)\end{array}$ & $\begin{array}{l}0.729 \\
(0.767)\end{array}$ & $\begin{array}{l}-0.197 \\
(0.160)\end{array}$ & $\begin{array}{l}1.440 \\
(0.280)\end{array}$ & -2.091 & -1.255 \\
$(0.040)$ & $(0.090)$ \\
\hline $\begin{array}{l}\text { NSDP per capita, gross fiscal } \\
\text { deficit and total transfers }\end{array}$ & $\begin{array}{l}-0.439 \\
(0.330)\end{array}$ & $\begin{array}{l}1.385 \\
(0.917)\end{array}$ & $\begin{array}{l}-0.674 \\
(0.250)\end{array}$ & $\begin{array}{l}0.359 \\
(0.640)\end{array}$ & $\begin{array}{l}-1.283 \\
(0.040)\end{array}$ & $\begin{array}{l}0.705 \\
(0.160)\end{array}$ & -2.377 & -1.481 \\
$(0.010)$ & $(0.090)$ \\
\hline $\begin{array}{l}\text { NSDP per capita, primary deficit, } \\
\text { gross fiscal deficit and total } \\
\text { transfers }\end{array}$ & $\begin{array}{l}-1.334 \\
(0.091)\end{array}$ & $\begin{array}{l}4.039 \\
(1.000)\end{array}$ & $\begin{array}{l}0.340 \\
(0.633)\end{array}$ & $\begin{array}{l}(1.390 \\
(1.000)\end{array}$ & $\begin{array}{l}0.182 \\
(0.050)\end{array}$ & $\begin{array}{l}0.278 \\
(0.020)\end{array}$ & $\begin{array}{l}0.045 \\
(0.020)\end{array}$ & $\begin{array}{l}0.109 \\
(0.070)\end{array}$ \\
\hline
\end{tabular}

Notes

(i) Sample period is 1981-2010.

(ii) The figures reported in the table are $p$-values.

(iii) For $G_{\tau}, G_{\alpha}, P_{\tau}$, and $P_{\alpha}$ the $p$-values are for a one-sided test based on the standard normal distribution.

(iv) For $G_{\tau}(B), G_{\alpha}(B), P_{\tau}(B)$, and $P_{\alpha}(B)$ the $p$-values are for a one-sided test based on a bootstrapped distribution.

(v) $\quad$ Lag (1), lead (1), lr window (1) and bootstrap 100.

(vi) The dependent variable in each case is total transfers. 
Table 9. ECM-based Multi-variate Cointegration: Tests for Structural Breaks.

\begin{tabular}{|c|c|c|c|c|c|c|c|c|}
\hline \multirow[t]{2}{*}{ State } & \multicolumn{2}{|c|}{ NSDP } & \multicolumn{2}{|c|}{ Debt } & \multicolumn{2}{|c|}{ Deficit } & \multicolumn{2}{|c|}{ Transfers } \\
\hline & p-value & $\begin{array}{l}\text { Break } \\
\text { date }\end{array}$ & p-value & $\begin{array}{l}\text { Break } \\
\text { date }\end{array}$ & p-value & $\begin{array}{l}\text { Break } \\
\text { date }\end{array}$ & p-value & $\begin{array}{l}\text { Break } \\
\text { date }\end{array}$ \\
\hline Andhra P & 0.0155 & 2002 & 0.0464 & 2000 & 0.0050 & 2005 & 0.0000 & 2005 \\
\hline Assam & 0.5107 & 1996 & 0.0351 & 1999 & 0.9341 & 1986 & 0.4744 & 2005 \\
\hline Gujarat & 0.0011 & 2000 & 0.0020 & 1999 & 0.0043 & 1998 & 0.0201 & 2004 \\
\hline Haryana & 0.2445 & 2004 & 0.0002 & 2002 & 0.8683 & 1986 & 0.0025 & 2004 \\
\hline Himachal P & 0.7285 & 1995 & 0.0189 & 1997 & 0.0000 & 2005 & 0.0413 & 2002 \\
\hline $\mathbf{J} \& \mathbf{K}$ & 0.7342 & 1995 & 0.0041 & 2000 & 0.0597 & 2003 & 0.2702 & 2001 \\
\hline Karnataka & 0.0235 & 2001 & 0.0319 & 2000 & 0.0038 & 2004 & 0.0691 & 2004 \\
\hline Kerala & 0.7823 & 2002 & 0.0917 & 2000 & 0.0119 & 1998 & 0.2055 & 2004 \\
\hline Madhya P & 0.6690 & 2005 & 0.0094 & 2000 & 0.0055 & 2003 & 0.0055 & 2004 \\
\hline Maharashtra & 0.0000 & 2004 & 0.0152 & 2001 & 0.0176 & 2003 & 0.0367 & 2004 \\
\hline Manipur & 0.1191 & 2002 & 0.0063 & 2002 & 0.0035 & 1999 & 0.0600 & 2001 \\
\hline Meghalaya & 0.8591 & 2004 & 0.3116 & 2000 & 0.2824 & 1997 & 0.0006 & 2005 \\
\hline Nagaland & 0.0030 & 2004 & 0.1233 & 2000 & 0.0000 & 2000 & 0.3788 & 2004 \\
\hline Orissa & 0.0000 & 2004 & 0.0075 & 1998 & 0.3555 & 1998 & 0.1822 & 2005 \\
\hline Punjab & 0.0000 & 2004 & 0.0463 & 1998 & 0.0011 & 2005 & 0.0152 & 2002 \\
\hline Rajasthan & 0.0825 & 2004 & 0.0287 & 1998 & 0.0087 & 1998 & 0.0016 & 2004 \\
\hline Sikkim & 0.2688 & 2002 & 0.7135 & 2004 & 0.0000 & 2002 & 0.2031 & 2005 \\
\hline Tamil Nadu & 0.3441 & 2005 & 0.0411 & 2000 & 0.9526 & 1986 & 0.0027 & 2004 \\
\hline Tripura & 0.0000 & 2004 & 0.5400 & 2000 & 0.0740 & 1999 & 0.1340 & 2002 \\
\hline Uttar P & 0.0047 & 2003 & 0.0897 & 1999 & 0.6695 & 1987 & 0.0000 & 2002 \\
\hline West Bengal & 0.0000 & 2004 & 0.0034 & 1999 & 0.8840 & 1986 & 0.0166 & 2003 \\
\hline
\end{tabular}

Notes:

i) The values reported in the first, third, fifth and seventh column are p-values.

ii) If the p-values are low, the break date reported in the second, fourth, sixth and eighth columns respectively is significant.

iii) For Arunachal Pradesh, Goa and Mizoram the tests did not yield any results. Hence, the tables only includes 21 states. 
Table 10. Selected ECM-based Multi-variate Cointegration Tests (additional control variables).

\begin{tabular}{|c|c|c|c|c|c|c|c|c|}
\hline & $G_{\tau}$ & $G_{\alpha}$ & $P_{\tau}$ & $P_{\alpha}$ & $G_{\tau}(B)$ & $G_{\alpha}(B)$ & $P_{\tau}(B)$ & $P_{\alpha}(B)$ \\
\hline $\begin{array}{c}\text { Gross fiscal deficit and } \\
\text { non-plan, plan transfers }\end{array}$ & $\begin{array}{c}-3.443 \\
(0.000)\end{array}$ & $\begin{array}{c}9.463 \\
(1.000)\end{array}$ & $\begin{array}{c}3.912 \\
(1.000)\end{array}$ & $\begin{array}{c}7.874 \\
(1.000)\end{array}$ & $\begin{array}{c}-1.289 \\
(0.250)\end{array}$ & $\begin{array}{c}7.863 \\
(0.050)\end{array}$ & $\begin{array}{c}0.563 \\
(0.100)\end{array}$ & $\begin{array}{c}5.937 \\
(0.050)\end{array}$ \\
\hline $\begin{array}{c}\text { NSDP per capita, primary } \\
\text { deficit, total transfers } \\
\text { (plan, non-plan) }\end{array}$ & $\begin{array}{c}-3.017 \\
(0.001)\end{array}$ & $\begin{array}{c}6.134 \\
(1.000)\end{array}$ & $\begin{array}{c}0.911 \\
(0.819)\end{array}$ & $\begin{array}{c}5.556 \\
(1.000)\end{array}$ & $\begin{array}{l}-3.017 \\
(0.070)\end{array}$ & $\begin{array}{l}6.134 \\
(0.000)\end{array}$ & $\begin{array}{l}0.911 \\
(0.060)\end{array}$ & $\begin{array}{l}5.556 \\
(0.030)\end{array}$ \\
\hline $\begin{array}{c}\text { NSDP per capita, primary } \\
\text { deficit, debt and non-plan } \\
\text { transfers }\end{array}$ & $\begin{array}{c}-2.570 \\
(0.999)\end{array}$ & $\begin{array}{c}-2.968 \\
(1.000)\end{array}$ & $\begin{array}{c}-6.474 \\
(1.000)\end{array}$ & $\begin{array}{c}-1.922 \\
(1.000)\end{array}$ & $\begin{array}{c}3.173 \\
(0.620)\end{array}$ & $\begin{array}{c}9.236 \\
(0.060)\end{array}$ & $\begin{array}{c}8.038 \\
(0.680)\end{array}$ & $\begin{array}{c}8.068 \\
(0.410)\end{array}$ \\
\hline $\begin{array}{c}\text { NSDP per capita, primary } \\
\text { deficit, debt and plan } \\
\text { transfers }\end{array}$ & $\begin{array}{c}-4.189 \\
(0.000)\end{array}$ & $\begin{array}{c}-3.854 \\
(1.000)\end{array}$ & $\begin{array}{c}-11.002 \\
(1.000)\end{array}$ & $\begin{array}{c}-3.320 \\
(1.000)\end{array}$ & $\begin{array}{c}-5.379 \\
(0.480)\end{array}$ & $\begin{array}{c}8.789 \\
(0.030)\end{array}$ & $\begin{array}{c}(0.486 \\
(0.290)\end{array}$ & $\begin{array}{c}7.350 \\
(0.020)\end{array}$ \\
\hline
\end{tabular}

Notes:

(i) Sample period is 1990-2010.

(ii) For $G_{\tau}, G_{\alpha}, P_{\tau}$, and $P_{\alpha}$ the $p$-values are for a one-sided test based on the standard normal distribution.

(iii) For $G_{\tau}(B), G_{\alpha}(B), P_{\tau}(B)$, and $P_{\alpha}(B)$ the $p$-values are for a one-sided test based on a bootstrapped distribution.

(iv) The dependent variable in the rows 3,4 and 5 is the last variable in column 1 .

(v) In rows 1 and 2 the first variable is the dependent variable.

(vi) The set of additional control variables used in the analysis includes social security expenditure (education, health expenditure), size of agricultural sector, size of industrial sector and ratio of interest payments to revenue receipts. 
Figure 1. Plan and Non-plan Transfers and Primary Deficits (1990-2010).

(a) Plan transfers and primary deficits.

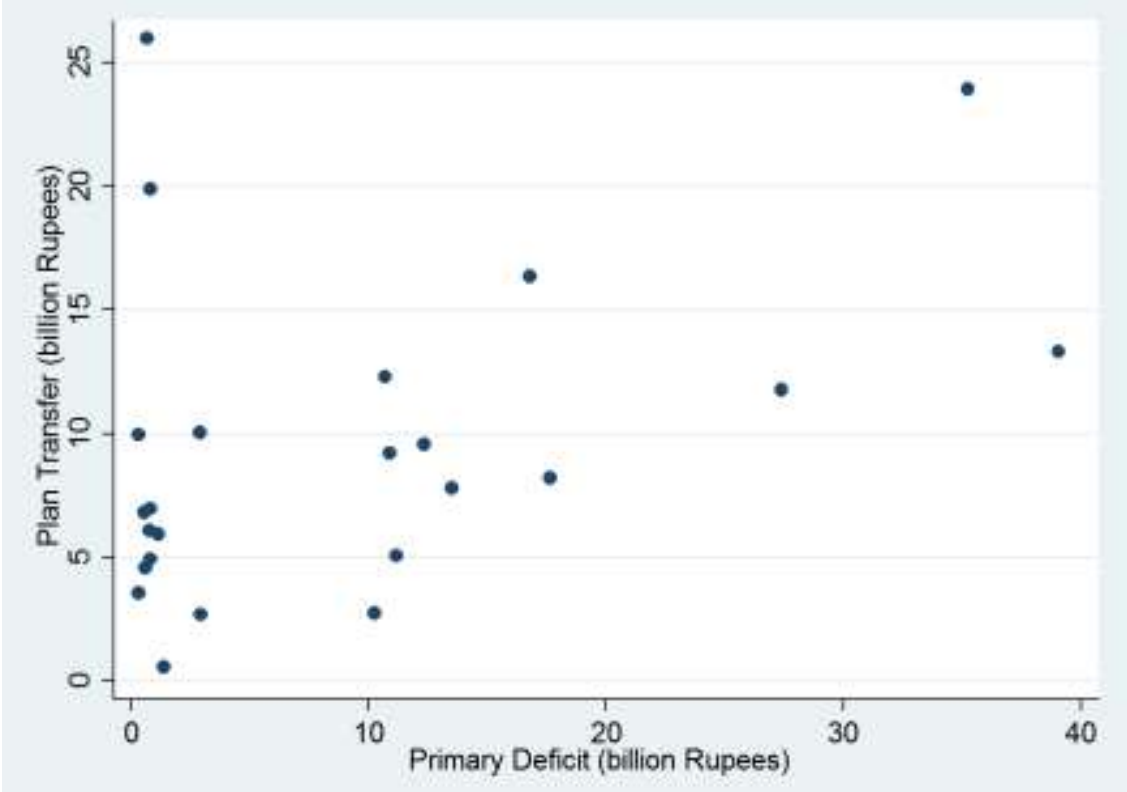

(b) Non-plan transfers and primary deficits.

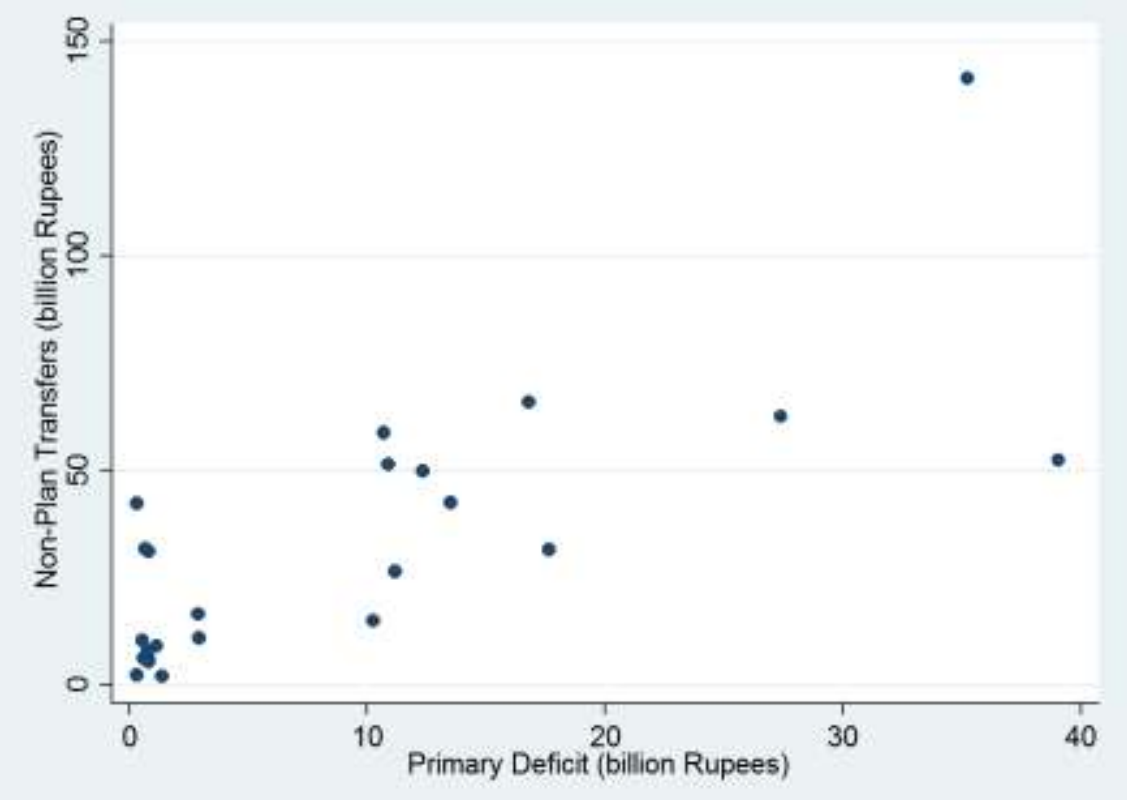


Figure 2. Adjusted Partial Residual Plots

(a) Plan transfers and primary deficits.

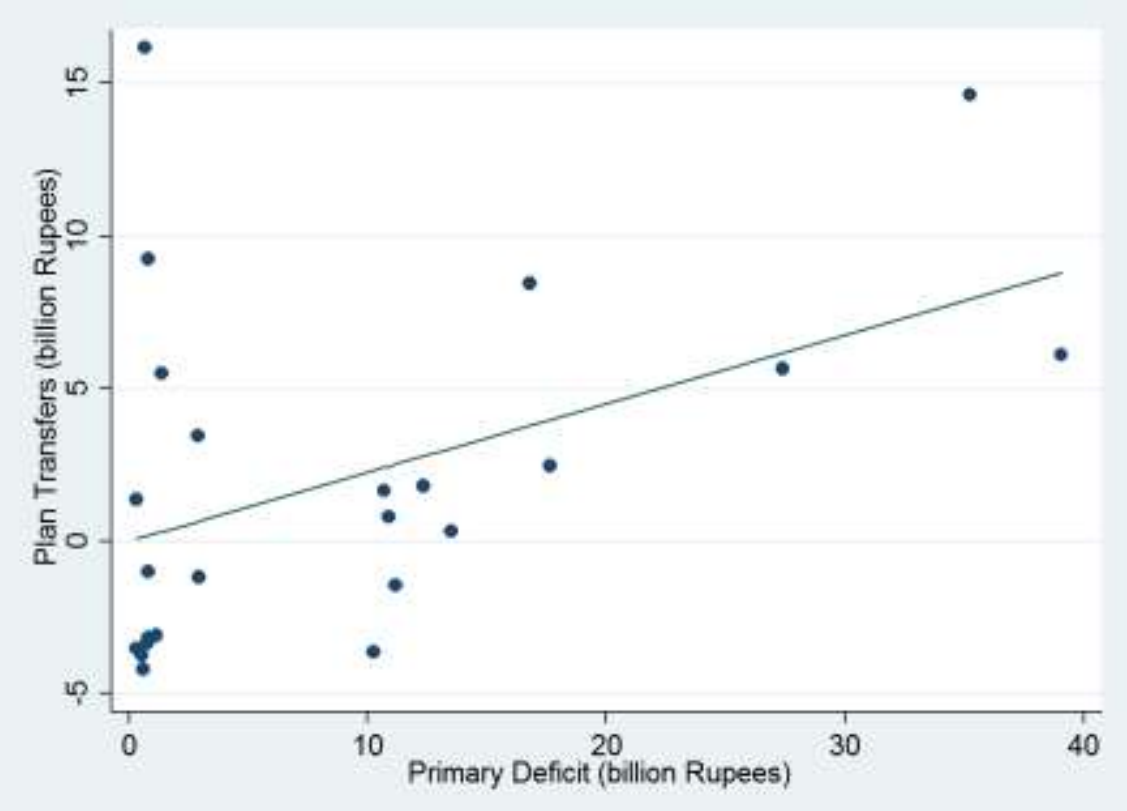

(b) Non-plan transfers and primary deficits.

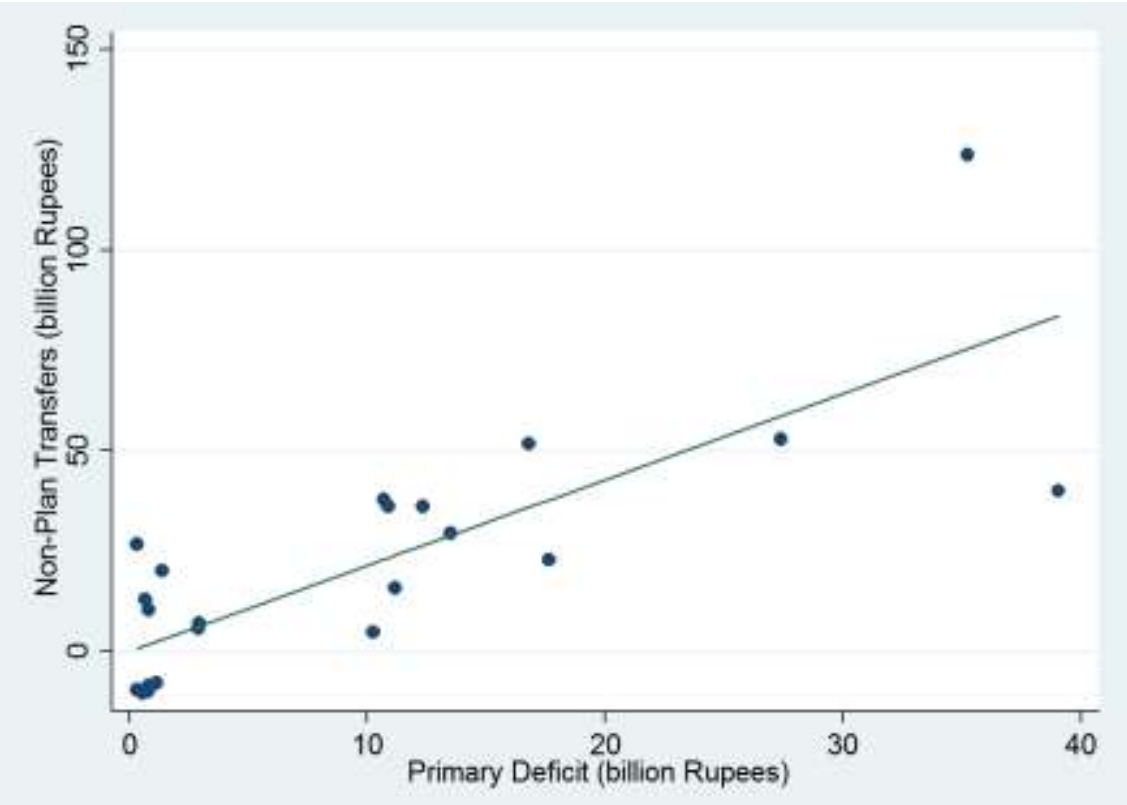

Note.

The figures graph each observation's residual plus its component predicted from NSDP per capita against the values of primary deficit. 